3. From: (Originating Organization)

Waste Management Strategic Planning

5. Proj.JProg./Dept./Div.: 33230

8. Originator Remarks:

This EDT is for the approval and release of HNF-SD-WM-018, Rev. O,

"Tank Farms Backlog Soil Sample and Analysis Results Supporting a Contained-In Determination"

11. Receiver Remarks:

11A. Design Baseline Document?

$\square$ Yes $\otimes$ No
Page 1 of

1. EDT

4. Reiated EDT No:

$\mathrm{N} / \mathrm{A}$

7. Purchasa Order No,

N/A

9. Equip./Companent Na.:

N/A

10. System/Bidg./Facility:

$\mathrm{N} / \mathrm{A}$

12. Major Assm. Dwg. No.:

$\mathrm{N} / \mathrm{A}$

13. Pormit/Permit Application No,

$\mathrm{N} / \mathrm{A}$

14. Required Response Date:

$2 / 10 / 97$
15

(A)

Nom
DATA TRANSMITTED

(C) Sheet (D) Rev. No.
(E) Title or Description of Data Transmitted

\begin{tabular}{|c|c|c|c|}
\hline (F) & (G) & $(\mathrm{H})$ & (I) \\
\hline $\begin{array}{c}\text { Approval } \\
\text { Desig- } \\
\text { nator }\end{array}$ & $\begin{array}{c}\text { Reason } \\
\text { for Trans- } \\
\text { mittal }\end{array}$ & $\begin{array}{c}\text { Origi- } \\
\text { nator } \\
\text { Dispo- } \\
\text { stion }\end{array}$ & $\begin{array}{c}\text { Receiv- } \\
\text { er } \\
\text { Dispo- } \\
\text { sition }\end{array}$ \\
\hline & & & \\
\hline
\end{tabular}

\begin{tabular}{|c|c|c|c|}
\hline (F) & (G) & $(\mathrm{H})$ & (I) \\
\hline $\begin{array}{c}\text { Approval } \\
\text { Desig- } \\
\text { nator }\end{array}$ & $\begin{array}{c}\text { Reason } \\
\text { for Trans- } \\
\text { mittal }\end{array}$ & $\begin{array}{c}\text { Origi- } \\
\text { nator } \\
\text { Dispo- } \\
\text { stion }\end{array}$ & $\begin{array}{c}\text { Receiv- } \\
\text { er } \\
\text { Dispo- } \\
\text { sition }\end{array}$ \\
\hline & & & \\
\hline
\end{tabular}

Ap

\begin{tabular}{|c|c|c|}
\hline 1 & HNF-SD-WM-TD-018 & $-\Theta-$ \\
\hline & & \\
\hline & & \\
\hline & & \\
\hline & & \\
\hline & & \\
\hline & & \\
\hline & & \\
\hline & & \\
\hline & 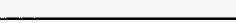 & \\
\hline
\end{tabular}

16.

\begin{tabular}{c} 
Approval Designator (F) \\
\hline $\begin{array}{c}\text { E, S, O, D OR N/A } \\
\text { Sec. } 12.7)\end{array}$ \\
Sec
\end{tabular}

17.

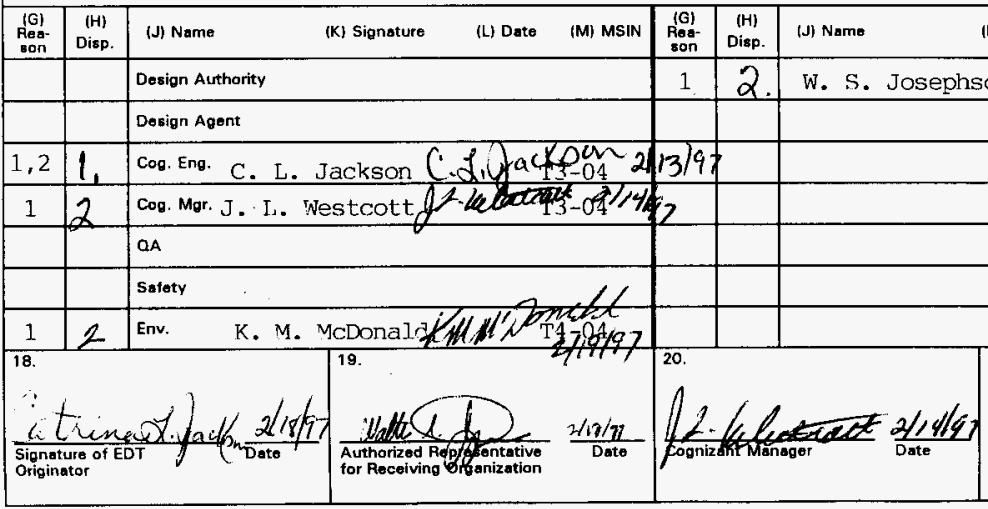

Disposition (H) \& (I)

\section{Review}

5. Post-Review

. Approval

3. Information

6. Dist (Rec

Tank Earms Backlog Soit.

Sample and Analysis

Results Supporting a

Contained-In Determination

KEY

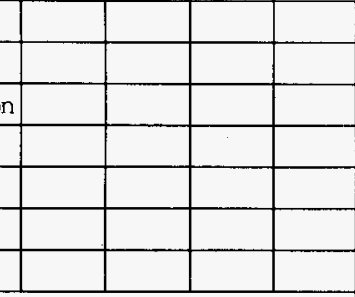




\title{
Tank Farms Backlog Soil Sample and Analysis Results Supporting a Contained-In Determination
}

\author{
Catrina L. Jackson \\ Rust Federal Services Hanford, Rich1and, WA 99352 \\ U.S. Department of Energy Contract DE-ACO6-87RL10930 \\ EDT/ECN: $\quad 703047$ \\ Org Code: 33230 \\ UC: $\quad 2020$ \\ B\&R Code: EW3130020 \\ Charge Code: A1224 \\ Total Pages: 39
}

Key Words: Backlog Soil Results

Abstract: The Backlog Waste Program was established to characterize and determine the proper disposal method for backlog soil waste. The backlog waste consisted of 2276 containers generated from Tank Farms operations during 1989 through early 1993. A sampling campaign was undertaken in 1992 and 1996. This report presents the results and evaluations from that campaign which, based on the "decision rule", supports a "Contained-In Determination."

TRADEMARK DISCLAIMER. Reference herein to any specific commercial product, process, or service by trade name, tradenark, manufacturer, or otherwise, does not necessarily constitute or imply its endorsement, recommendation, or favoring by the United States Government or any agency thereof or its contractors or subcontractors.

Printed in the United States of America. To obtain copies of this document, contact: WHC/BCS Document Control Services, P.O. Box 1970, Mailstop H6-08, Richland WA 99352, Phone (509) 372-2420; Fax (509) 376-4989.
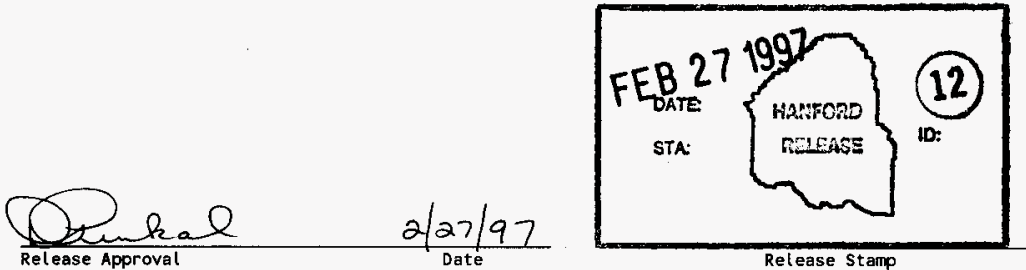

Release stamp

\section{Approved for Public Release}




\section{Table of Contents}

$1.0 \quad$ INTRODUCTION $\ldots \ldots \ldots \ldots \ldots \ldots \ldots \ldots \ldots \ldots \ldots \ldots \ldots \ldots \ldots \ldots \ldots$

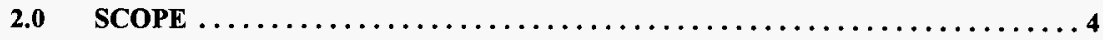

3.0 TEST RESULTS $\ldots \ldots \ldots \ldots \ldots \ldots \ldots \ldots \ldots \ldots \ldots \ldots \ldots \ldots \ldots \ldots \ldots \ldots$

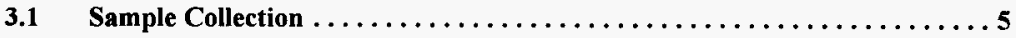

3.1.1 Sample Collection Campaign for $1996 \ldots \ldots \ldots \ldots \ldots \ldots \ldots$

3.1.2 Sample Collection Campaign for 1992

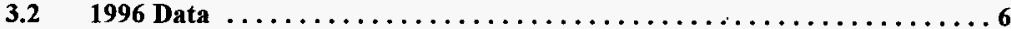

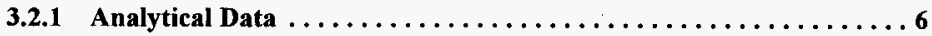

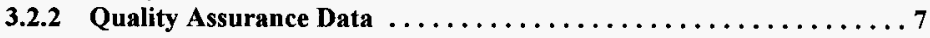

$3.3 \quad 1992$ Data $\ldots \ldots \ldots \ldots \ldots \ldots \ldots \ldots \ldots \ldots \ldots \ldots \ldots \ldots \ldots \ldots$

3.3.1 Analytical Data . . . . . . . . . . . . . . . . . . . .

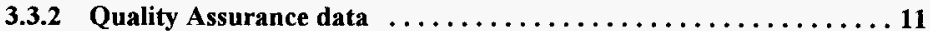

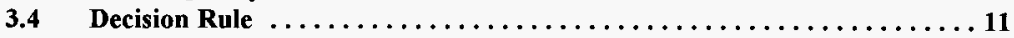

3.4.1 Evaluation of Data for Decision Making

4.0 CONCLUSION $\ldots \ldots \ldots \ldots \ldots \ldots \ldots \ldots \ldots \ldots \ldots \ldots \ldots \ldots \ldots \ldots \ldots \ldots \ldots \ldots$

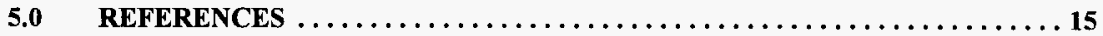


HNF-SD-WM-TD-018

Rev. 0

\section{List of Tables}

I. Constituents of Concern Thresholds...................................................pp. 8,9

II. Detected Constituents of Concern \& Maximum Results........................p. 10

III. State Persistent Chemicals: Maximum Results \& Percentages.......................pp. 13,14 
HNF-SD-WM-TD-018

Rev. 0

\section{APPENDICES}

I. Appendix A: 1996 Laboratory Results

II. Appendix B: 1996 Field Data

III. Appendix C: 1996 Quality Assurance Data

IV. Appendix D: 1992 Laboratory Results.

V. Appendix E: 1996 Calculations 


\subsection{INTRODUCTION}

Soil waste is generated from Tank Farms and associated Tank Farms facilities operations. The soil is a mixed waste because it is an environmental media which contains tank waste, a listed mixed waste. The soil is designated with the listed waste codes (F001 through F005) which have been applied to all tank wastes. The scope of this report includes Tank Farms soil managed under the Backlog program. The Backlog Tank Farm soil in storage consists of 769 drums and 5 boxes (originally 828 drums).

The Backlog Waste Program dealt with 2276 containers of solid waste generated by Tank Farms operations during the time period from 1989 through early 1993. The containers were mismanaged by being left in the field for an extended period of time without being placed into permitted storage. As a corrective action for this situation, these containers were placed in interim storage at the Central Waste Complex (CWC) pending additional characterization. The Backlog Waste Analysis Plan (BWAP) (RL 1993) was written to define how Backlog wastes would be evaluated for proper designation and storage. The BWAP was approved in August 1993 and all work required by the BWAP was completed by July 1994.

This document presents results of testing performed in 1992 \& 1996 that supports the attainment of a Contained-In Determination for Tank Farm Backlog soils. The analytical data contained in this report is evaluated against a prescribed decision rule. If the decision rule is satisfied then the Washington State Department of Ecology (Ecology) may grant a Contained-In Determination. A Contained-In Determination for disposal to an unlined burial trench will be requested from Ecology. The decision rule and testing requirements provided by Ecology are described in the Tank Farms Backlog Soil Sample Analysis Plan (SAP) (WHC 1996).

\subsection{SCOPE}

The purpose of this report is to present and evaluate the test data per the decision rule for the purpose of obtaining a Contained-In determination for Tank Farms Backlog soil. The document will present analysis data collected per the SAP and analysis data collected in 1992 . These data will be compared to the acceptance levels specified in the SAP, if the decision rule is satisfied then a request for a Contained-In Determination will be submitted to Ecology.

\subsection{TEST RESULTS}

\subsection{Sample Collection}

Two sampling and testing campaigns were undertaken in 1992 \& 1996. In the campaign of 1992 eight drums were sampled and tested. Then the samples were split and sent to Westinghouse Hanford Company (WHC) and Ecology contract laboratories for analysis. The Ecology lab results are used here in the decision making. 
There were a total of 70 drums sampled in 1996. Three of the 70 were reanalyses of 1992 drums so only 67 new drums were tested. Specific sample analyses for constituents of major concern were requested and the results were reported per requirements in the SAP.

\subsubsection{Sample Collection Campaign for $\mathbf{1 9 9 6}$}

The project in 1996 consisted of sampling 70 drums, field testing samples and testing the samples in a laboratory. Samples were sent to Waste Sampling and Characterization Facility (WSCF) laboratory for analysis. Duplicate or split samples for selected drums were sent to Quanterra and Ecology laboratory. Samples were collected and tested in accordance with Test Methods for the Evaluation of Solid Waste-Physical/Chemical Methods, SW-846 (EPA 1986) methods and protocols (see reference section). The dose rates on the samples did not exceed 5 $\mathrm{mrem} / \mathrm{hr}$. There were two types of samples taken, a grab sample for Volatile Organic Analysis (VOA) and Semivolatile Organic Analysis (SVOA) and a composite sample. The grab samples were collected from the interior of the drum. The sample bottles were filled immediately following the extraction of the soil. The composite samples were collected by extracting at least one core of soil, depositing the core(s) in a bowl, mixing the soil and then filling the sample bottles. Also a set of VOA trips for each day, 6 sets of field blanks and 4 split samples were sent to the laboratories as field QA samples. The blanks consisted of a clean sand material.

The analyses requested for the samples sent to WSCF and Quanterra laboratories were Toxicity Characteristic Leaching Procedure (TCLP) metals, Inductive Coupled Plasma Spectroscopy (ICP) metals conducted on 19 samples, SVOA, VOA, sulfide, cyanide, flashpoint (as needed) and $\mathrm{pH}$, herbicides, pesticides and radiochemistry.

\subsubsection{Sample Collection Campaign for 1992}

Eight drums of backlog soil were sampled. The samples were split and tested at two different laboratories. One set of samples was sent for analysis to a laboratory under contract with WHC, the other set was relinquished to Ecology personnel who sent the samples to a different laboratory for analysis.

Samples were collected in November of 1992 and managed in adherence with Test Methods for the Evaluation of Solid Waste-Physical/Chemical Methods, SW-846 (EPA 1986) methods and protocols. Twenty drums were selected by Ecology for sample collection and testing, but only eight from SX Farm were sampled due to delays and difficulties. All dose rates from the selected drums are less than $10 \mathrm{mrem} / \mathrm{Hr}$. Samples were collected from the top inch of soil for volatile organic analysis. All other samples were collected by obtaining at least one core, compositing the core into a bowl and then filling the sample bottles.

A set of five trip blanks were also sent to each laboratory as field QA samples. The trip blanks 
were a clean sand material.

During sample collection the vapor space in the drum was monitored using a photo ionizing detector. No vapors were detected.

Analyses requested for Ecology samples were anions, ICP metals, VOA, SVOA, sulfide and cyanide reactivity, $\mathrm{pH}$, herbicides and pesticides

\section{$3.2 \quad 1996$ Data}

The 1996 data is comprised of laboratory analysis and field data for 70 drums that were sampled and analyzed for the constituents of concern.

\subsubsection{Analytical Data}

The laboratory and field results represent the analytical data for the 70 drums sampled and analyzed in 1996. Three of the 70 drums were retests for specific analyses of the 1992 tests. Major data qualifications are shown in the Appendices. The laboratory results (Appendix A) were extracted from validated summary data packages provided by the laboratory. The field data results are listed in Appendix B.

There were four samples tested for pesticides that possessed a major deficiency due to low surrogate recoveries. These results are not be used for decision making.

A major deficiency is noted in hold time exceedances for pesticide analyses. The hold time exceedance was not significant based on scientific studies which indicate that the pesticides in question (organochlorine pesticides) are persistent and do not readily degrade. Significant losses of organochlorine pesticides are usually measured in years. The amount of degradation that would occur due to weeks or months of the hold time exceedance would be very small and difficult to measure (see pesticide listings in reference section). For this reason, the results for the pesticides that are qualified for hold time deficiency are used in the decision making.

A low spike recovery of silver was noted as a major deficiency. The spike recoveries are not significant because: 1) the analytical results were non-detectable and 2) in all cases the results are greatly below the regulatory threshold by a factor of 58 . Therefore, despite major deficiency the quality of the data results for the silver are adequate for making a decision.

A major deficiency is noted in the semivolatile analyses due to a surrogate recovery of less than $10 \%$. These data are not useable for decision making for some semivolatile constituents. So 73 results remained for decision making for some semivolatile constituents. The constituents are noted in Appendix A. The surrogate and low spike recoveries are chemicals which are added to a sample to confirm the effectiveness of the test procedure. A low recovery indicates an error 
may have occurred that may cause the results to be low, thus biasing the results

It may be noted that Polychlorinated Biphenyls (PCBs) were detected in 40 soil samples and listed in Appendix A. They are not used for decision making because PCBs are not listed as ( according to the SAP) constituents of concern to obtain a Contained-In Determination.

Field data recorded includes: Organic Vapor Monitoring results (OVM), paint filter test, pH and recorded room temperature when a drum was opened. As per the SAP if no liquids were present in the soil samples, the flashpoint test was not necessary. Field data is presented in Appendix B.

A drum of absorbed liquid was tested and reported. The results are presented as miscellaneous data (Appendix A). The results were not included in the decision making.

\subsubsection{Quality Assurance Data}

Analysis of deionized water used for dampening the soil during sample collection was performed in the 1996 sampling campaign. Insignificant levels of contamination are reported in the water. The data was reported as miscellaneous data (Appendix A).

The trip blanks were tested for volatiles in the 1996 data results detected acetone. The presence of the constituent could be the result of contamination of samples, producing a false positive. As the test results are well below the Model Toxic Control Act (MTCA) threshold (listed in Tables $1 \& 2$ ), no attempt was made to correct for the bias in the acetone results. The data is included in the decision making.

Duplicate samples of selected drums were sent to Quanterra. The analyses of both laboratories detected the constituents: barium, benzo(b)fluoranthene and PCBs. It was noted that the results for barium analyzed in the Quanterra laboratory were greater than the results taken from WSCF by a factor of 2 . A difference in the results between the laboratories appears to exist for barium. The higher Quanterra result was used for the decision making.

\subsection{Data}

\subsubsection{Analytical Data}

Ecology \& WHC tested samples from eight drums of soil in 1992. The Ecology results were included in the Appendix D and are used for decision making. The Ecology data was not validated but rather used as provided. All of these results are used for decision making except those retested in 1996.

It is noted that one sulfide-releasable and two flashpoint tests exceeded their threshold limits. To confirm the results, the constituents were reanalyzed in 1996. The new analyses yielded results 
Table 1. Constituents of Concern Thresholds

\begin{tabular}{|c|c|c|}
\hline Chemical Name & $\begin{array}{l}\text { Characteristic Threshold } \\
\text { (mg/L) }\end{array}$ & $\begin{array}{l}\text { MTCA Threshold } \\
\text { (mg/kg) }\end{array}$ \\
\hline Ignitability & fp. $<140^{\circ} \mathrm{F}$ and free liquid & na \\
\hline Corrosivity & $\mathrm{pH}<2$ or $\mathrm{pH}>12.5$ & na \\
\hline Reactive CN (mg HCN/kg) & $250 \mathrm{mg} \mathrm{HCN} / \mathrm{kg}$ & \\
\hline Reactive S (mg $\mathrm{H}_{2} \mathrm{~S} / \mathrm{kg}$ ) & $500 \mathrm{mg} \mathrm{H}_{2} \mathrm{~S} / \mathrm{kg}$ & \\
\hline Acetone & na & 8000 \\
\hline Arsenic & 5 & na \\
\hline Barium & 100 & na \\
\hline Benzene & 0.5 & na \\
\hline Cadmium & 1 & na \\
\hline Carbon Tetrachloride & 0.5 & na \\
\hline Chlordane & 0.03 & na \\
\hline Chlorobenzene & 100 & na \\
\hline Chloroform & 6 & na \\
\hline Chromium & 5 & na \\
\hline o-Cresol \& m-Cresol & 200 & 400 \\
\hline p-Cresol & 200 & 4000 \\
\hline 2,4-D & 10 & na \\
\hline 1,4-Dichlorobenzene & 7.5 & na \\
\hline 1,2-Dichloroethane & 0.5 & na \\
\hline 1,1-Dichloroethylene & 0.7 & na \\
\hline 2,4-Dinitrotoluene & 0.13 & na \\
\hline Endrin & 0.02 & na \\
\hline Heptachlor epoxide & 0.008 & na \\
\hline Hexaclorobenzene & 0.13 & na \\
\hline Hexaclorobutadiene & 0.5 & na \\
\hline Hexachloroethane & 3 & na \\
\hline
\end{tabular}


Table 1. Constituents of Concern Thresholds (cont'd)

\begin{tabular}{|c|c|c|}
\hline Chemical Name & $\begin{array}{c}\text { Characteristic Threshold } \\
(\mathrm{mg} / \mathrm{L})\end{array}$ & $\begin{array}{c}\text { MTCA Threshold } \\
(\mathbf{m g} / \mathrm{kg})\end{array}$ \\
\hline Lead & 5 & na \\
\hline Lindane & 0.4 & na \\
\hline Mercury & 0.2 & na \\
\hline Methoxychlor & 10 & na \\
\hline Methyl Ethyl Ketone & 200 & 48000 \\
\hline Methyl Isobutyl Ketone & na & 4000 \\
\hline Methylene Chloride & na & 133 \\
\hline Nitrobenzene & 2 & na \\
\hline Pentachlorophenol & 100 & na \\
\hline Pyridine & 5 & na \\
\hline Selenium & 1 & na \\
\hline Silver & 5 & na \\
\hline Tetrachloroethylene & 0.7 & na \\
\hline Toxaphene & 0.5 & na \\
\hline 2,4,5-TP (silvex) & 1 & na \\
\hline 1,1,1-Trichloroethane & na & 72000 \\
\hline Trichloroethylene & 0.5 & na \\
\hline 2,4,5-Trichlorophenol & 400 & na \\
\hline 2,4,6-Triclorophenol & 2 & na \\
\hline Vinyl Chloride & 2 & na \\
\hline Polycyclic Aromatic Hydrocarbon & $1 \%$ PAH & na \\
\hline Halogenated Hydrocarbon & $.01 \% \mathrm{HH}$ & na \\
\hline criteria toxic & $.001 \% \mathrm{EC}$ & na \\
\hline
\end{tabular}

Note: This table is representative of all major constituents of concern and the associated thresholds. 
Table 2. Detected Constituents of Concern and Maximum Results

\begin{tabular}{|c|c|c|}
\hline Chemical Name & $\begin{array}{l}\text { Result Converted to Threshold } \\
(\mathrm{mg} / \mathrm{L})\end{array}$ & Maximum Results \\
\hline Ignitability & & $>100^{\circ} \mathrm{C}$ \\
\hline Corrosivity & & 9.72 \\
\hline Reactive CN (mg $\mathrm{HCN} / \mathrm{kg}$ ) & 4.495 & $89.9 \mathrm{mg} / \mathrm{kg}$ \\
\hline Reactive $\mathbf{s}$ (mg H2s/kg) & 12.8 & $256 \mathrm{mg} / \mathrm{kg}$ \\
\hline Acetone & .0044 & $0.088 \mathrm{mg} / \mathrm{kg}$ \\
\hline Barium & 0.677 & $.677 \mathrm{mg} / \mathrm{L}$ \\
\hline Chromium & 0.166 & $0.166 \mathrm{mg} / \mathrm{L}$ \\
\hline o-Cresol \& m-Cresol & .00265 & $0.053 \mathrm{mg} / \mathrm{kg}$ \\
\hline $2,4-D$ & .0000275 & $0.00055 \mathrm{mg} / \mathrm{kg}$ \\
\hline Lead & 2.99 & $2.99 \mathrm{mg} / \mathrm{L}$ \\
\hline Mercury & .00055 & $0.011 \mathrm{mg} / \mathrm{kg}$ \\
\hline Methyl Ethyl Ketone & .0003 & $0.006 \mathrm{mg} / \mathrm{kg}$ \\
\hline Methyl Isobuty 1 Ketone & .0016 & $0.032 \mathrm{mg} / \mathrm{kg}$ \\
\hline Methylene Chloride & .00015 & $0.003 \mathrm{mg} / \mathrm{kg}$ \\
\hline silver & 0.086 & $.086 \mathrm{mg} / \mathrm{L}$ \\
\hline $2,4,5-T P$ (silvex) & .00035 & $0.007 \mathrm{mg} / \mathrm{kg}$ \\
\hline $\begin{array}{l}\text { Polycyclic Aromatic } \\
\text { Hydrocarbon }\end{array}$ & 0.00034798 & na \\
\hline Halogenated Hydrocarbon & 0.00790568 & na \\
\hline criteria toxic & 0.008 & na \\
\hline
\end{tabular}

Note: This table consists of detected constituents of concern and the maximum results for each. 
detected below the threshold limits. The 1996 results were used for decision making, in lieu of the 1992 results for the constituents because the results are corroborated by the 1992 WHC test results.

\subsubsection{Quality Assurance data}

Eight split samples were taken by WHC with the Ecology samples. The WHC flashpoints and reactive sulfide results were below regulatory thresholds, which did not corroborate with the Ecology results. The other WHC results agree with the Ecology results.

\subsection{Decision Rule}

The decision rule stated here is extracted verbatim from the SAP. Each result is compared to the appropriate standard or threshold. If a listed constituent is detected, then the result will be compared to the MTCA standard or regulatory threshold for the characteristic, which ever is lower. If not a listed constituent then the result is compared to the constituent characteristic regulatory threshold. Washington State criteria thresholds are also evaluated for the listed constituents (Table 1). The statistical test to determine if a constituent is less than its threshold for the waste stream is dependent upon the distribution of the data. The decision rule is:

1. For each constituent of concern 71 results (except 6010 metals, 7 results is adequate) must exist and the distribution of a transform (e.g., lognormal) is determined to be normal. If so, a confidence interval approach is employed. The upper confidence interval on the true soil concentration is less than the soil threshold shown on Table 1. Statistical tests shall be performed at a Type 1 error level of 0.05 (one-tailed test of the null hypothesis that the true soil concentration of a hazardous substance exceeds the threshold). If a transform is not normal then proceed to step 2.

2. For each constituent of concern 71 results (except 6010 metals, 7 results is adequate) must exist and all the results (nonparametric approach) must be below the appropriate standard of Table 1. For each exceedance four more tests must be performed that are below the appropriate standard of Table 1 for that constituent.

If either 1 or 2 above are successful for each constituent of concern listed on Table 1 then, statistically adequate data has been collected to obtain a Contained-In determination, thus, satisfying the Data Quality Objective (DQO). The purpose of the Data Quality Objective is to demonstrate that constituents of concern are below MTCA standards for listed constituents and that the soil possesses no dangerous waste characteristics or criteria.

\subsubsection{Evaluation of Data for Decision Making}

In evaluating the data for satisfaction of the decision rule, decision rule option 2 is used. A 
determination of the normality of a transform of the data was not attempted.

There are 67 new (1996) and 8 old (1992) points existing for a possible total of 75 results. After considering the data qualifications described in sections $3.2 \& 3.3$ for each constituent there exists 71 to 75 valid results for decision making. As stated in section 3.2.1 the 71 pesticide and 73 of some semivolatile constituents possess adequate quality for decision making. Thus, the minimum requirement of 71 results was met for each constituent. Therefore, enough quality data exists to make a decision per the decision rule in the SAP.

The applicable MTCA standards and regulatory thresholds for characteristics or state criteria for major constituents of concern are listed in Table 1. As shown in Table 2 all detected results are less than the standards (thresholds). If not shown in Table 2, the constituent was not detected and the constituent detection limit is below the threshold. The maximum result listed in Table 2 is the result that is the greatest of the qualified data for that constituent.

Calculations were performed to determine the state of the Washington criteria status. The presence of Polycyclic Aromatic Hydrocarbons (PAH), Halogenated Hydrocarbon $(\mathrm{HH})$ and Toxicity characteristics (EC) results are all below the threshold limits. Calculations are provided in Appendix E (PAH \& HH Table and the EC\% analyses). The EC\% analyses are shown in the corresponding Solid Waste Engineering Analysis sheets. All of the calculations employ the maximum results and weight percentages for each constituent (Table 3), used in decision making.

\subsection{CONCLUSION}

An adequate amount of quality data ( 71 results) exists to satisfy the decision rule. The analytical results for the detected major constituents of concern fell far below the threshold limits established per the decision rule. Thus, the waste is suitable to obtain a Contained-In Determination for Tank Farm Backlog soil from Ecology. 
Table 3. State Persistent Chemicals: Maximum Results \& Percentages

\begin{tabular}{||l|l|l||}
\hline \multicolumn{2}{|l||}{ Polycyclic Aromatic Hydrocarbons } \\
(PAH)
\end{tabular}


HNF-SD-WM-TD-018

Rev. 0

Table 3. State Persistent Chemicals: Maximum Results \& Percentages (cont'd)

\begin{tabular}{|c|c|c|}
\hline \multicolumn{3}{|c|}{$\begin{array}{l}\text { Halogenated Hydrocarbon } \\
(\mathrm{HH})\end{array}$} \\
\hline Chemical Name & $\begin{array}{c}\text { Maximum Result } \\
(\mathrm{mg} / \mathrm{kg})\end{array}$ & Weight\% \\
\hline 2,4-D & 0.011 & 0.0000011 \\
\hline Methyl Ethyl Ketone & 0.006 & 0.0000006 \\
\hline Methyl Isobutyl Ketone & 0.032 & 0.0000032 \\
\hline PCBs & 79 & 0.0079 \\
\hline 2,4,5-TP (Silvex) & 0.007 & 0.0000007 \\
\hline Total (HH)\% & & $0.0079056 \%$ \\
\hline
\end{tabular}

Notes: 1. The table is representative of PAH \& HH constituents of concern that have been detected.

2. The PAH \& HH constituents are also listed in Tables 1 \& 2.

3. The total PAH and HH percents are the sums of the weight percents of the constituents.

4. The weight $\%$ is the result of multiplying the maximum result by 10,000 . 
HNF-SD-WM-TD-018

Rev. 0

\subsection{REFERENCES}

DOE/RL 1993, Waste Analysis Plan for Confirmation of Completion of Tank Farms Backlog Soil Waste Designation, DOE-RL-93-70, Rev. 1, U.S. Department of Energy, Richland Operations Office, Richland, WA.

EPA 1986, Test Methods for the Evaluation of Solid Waste-Physical / Chemical Methods, SW-846, 3rd Ed., U.S. Environmental Protection Agency, Washington, D.C.

J. L. Westcott, to R. D. Pierce, et al., "Backlog Soil: Data Supporting Characterization," 87600-95-JLW-004, August 31, 1995, pp. 2-3.

K. B. Wehner, to J. L. Westcott," Degradation and Persistence of Organochlorine Pesticides in Soil," October 25, 1996.

WHC 1996, Tank Farm Soils Sample \& Analysis Plan, WHC-SD-WM-TP-440, Rev. 0, Westinghouse Hanford Company, Richland, WA. 
HNF-SD-WM-TD-018

Rev. 0

\section{APPENDIX A}

\section{Laboratory Results}

Comprised of 7 pages including the cover page 


\section{Glossary of Organic Data Reporting Qualifiers}

B- Indicates the constituent was analyzed for and detected in the associated laboratory blank. This qualifier is applied by the laboratory. During the process of data validation this qualifier may be replaced by other appropriate qualifiers as defined by the validation procedures. The associated data should be considered usable for decision making purposes.

U- Indicates the constituent was analyzed for and not detected. The concentration reported is the sample quantitation limit corrected for aliquot size, dilution and percent solids (in the case of solid matrices) by the laboratory. The associated data should be considered usable for decision making purposes.

UJ- Indicates the constituent was analyzed for and not detected. Due to a minor quality control deficiency identified during data validation the concentration reported may not accurately reflect the sample quantitation limit. The associated data should be considered usable for decision making purposes.

J- Indicates the constituent was analyzed for and detected. This qualifier may be applied by the laboratory to indicate a concentration which is less than the contract required quantitation limit (CRQL) but greater than the instrument detection limit (IDL). During data validation this qualifier may be applied to indicate a minor quality control deficiency. However, in either case, the associated data should be considered usable for decision making purposes.

NJ- Indicates presumptive evidence of a constituent at an estimated value. This qualifier is normally applied to GC analysis data (such as organochlorine pesticide and PCB data). The associated data should be considered usable for decision making purposes.

N- Indicates presumptive evidence of a constituent. This qualifier is normally applied to GC analysis data (such as organochlorine pesticide and PCB data). The associated data should be considered usable for decision making purposes.

JN- Indicates a tentatively identified compound (TIC) whose concentration and identification have been determined to be valid as a result of data validation. The associated data should be considered usable for decision making purposes.

UJN- Indicates a tentatively identified compound (TIC) that has been determined to be presumptive and valid $(J N)$ in terms of identification and quantitation and has been qualified as undetected (U) due to associated blank contamination.

UR- Indicates the constituent was analyzed for and not detected. The concentration reported has been qualified as unusable due to a major quality control deficiency identified during data validation. The associated data should be considered unusable for decision making purposes.

R- Indicates the constituent was analyzed for and detected. The concentration reported has been qualified as unusable due to a major quality control deficiency identified during data validation. The associated data should be considered unusable for decision making purposes. 


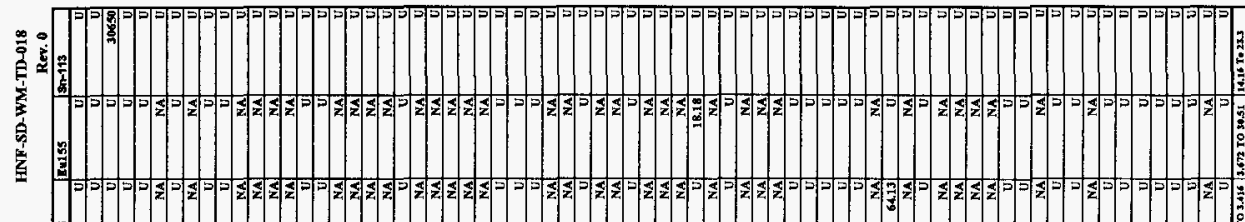

3.

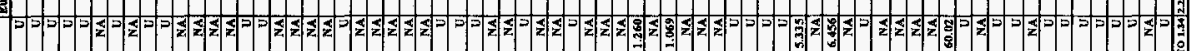
:

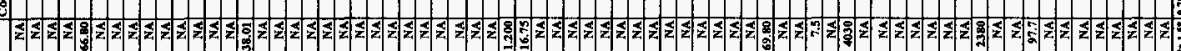
象 .

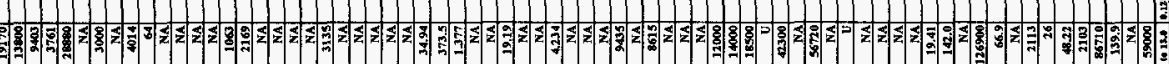

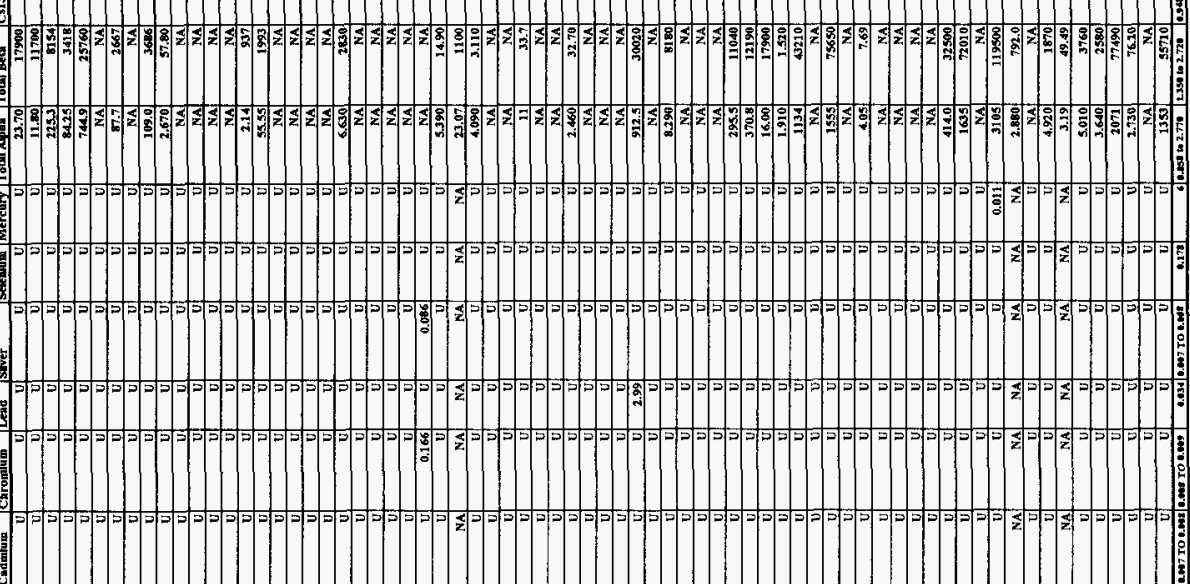

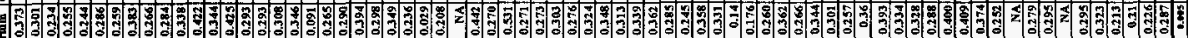

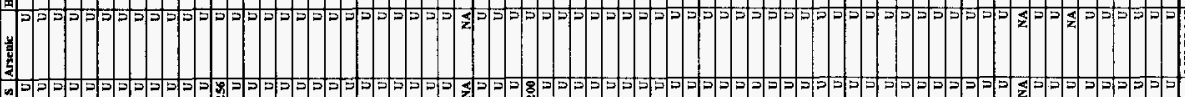

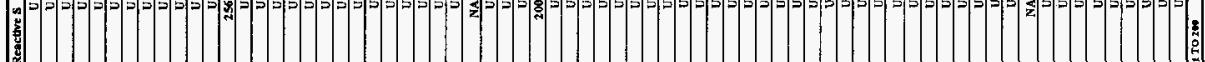

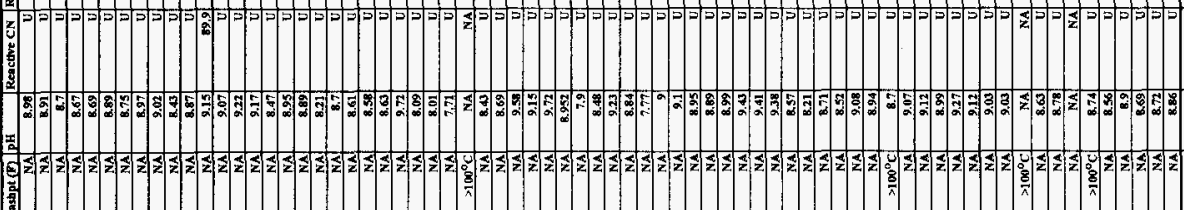

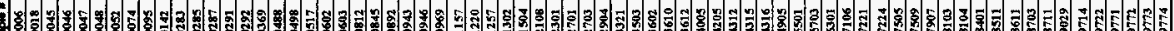

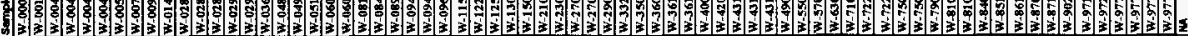

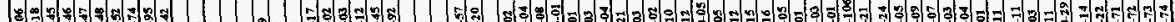

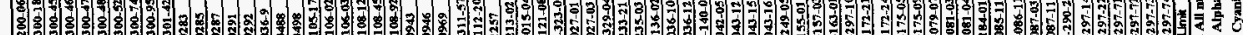

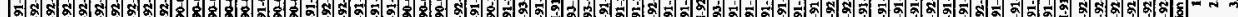

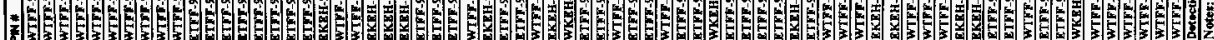




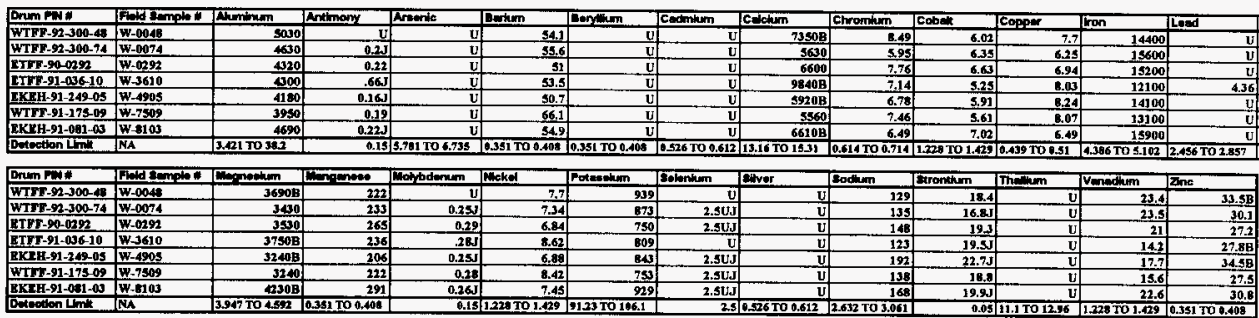

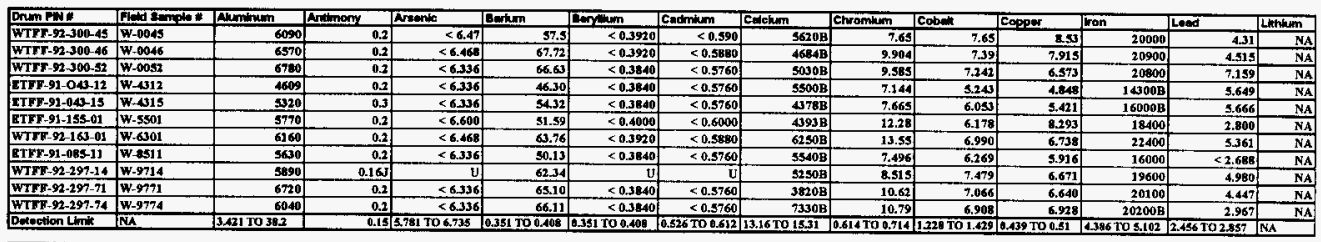

\begin{tabular}{|c|c|c|c|c|c|c|c|c|c|c|c|c|c|}
\hline Drmm Fil: & 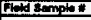 & 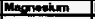 & Denpentes: & Wohtydentum & Milckol & Potentringm & solenium & Siver & $5000 \mathrm{~m}$ & Sirontiem & Theritem & Varadlum & Znc \\
\hline WTVT-92-300-45 & $W_{-0.045}$ & $\begin{array}{r}4330 \\
\end{array}$ & 289 & $\mathbf{U}$ & 92218 & 1050 & 1AB & $<0.590$ & 270 & \begin{tabular}{|r|}
15.9 \\
\end{tabular} & $<12,4$ & 43.1 & $41.5 B$ \\
\hline WTTT-9R-300-46 & W-0046 & 434 & 282.6 & U & 10.24B & 1144 & 3.8B & $<0.5890$ & 278.6 & 149 & $<12.45$ & 42.54 & $41,85 B$ \\
\hline WTrr-92-300-52 & W-00sz & 4006 & 312,8 & U & $9.734 \mathrm{~B}$ & 1307 & $\mathrm{u}$ & $<0.5760$ & 197.2 & 15.4 & $<12.19$ & 46,87 & 44018 \\
\hline ETPF-91-0412 & $w-4512$ & 3124 & 225.6 & $\mathbf{U}$ & 6.712 & 809.0 & 10B & $<0.5760$ & 343.6 & 19.1 & $<12.19$ & 28.37 & $35.41 \mathrm{~B}$ \\
\hline ETPF-91-044-15 & W.4315 & 3303 & 213.9 & v & 6.969 & 975.2 & $7 \mathrm{~B}$ & $<0.5760$ & 324.3 & 20.0 & $<12.19$ & 34.12 & $38,0 S B$ \\
\hline ETET-91-155-01 & W-5s01 & 3594 & 240.0 & v & $10.49 \mathrm{~B}$ & $84,3,2$ & S.BAD & $\angle 0.6000$ & 207.2 & 13.9 & $<12,70$ & 38,33 & $40.51 \mathrm{~B}$ \\
\hline WITE-92-163-01 & W-6301 & 261 & 321,4 & $\mathrm{U}$ & B.651B & 1075 & 6.5B & $<0.5880$ & 2494 & 18.0 & $<12.49$ & 4534 & 5E.BAB \\
\hline ETVT-91-005-11 & W-s5il & 3334 & 226.7 & t) & $7.81 \mathrm{BB}$ & 998.3 & u & $<0.5760$ & 232.5 & 20,9 & $<12.19$ & 32.50 & $34.29 \mathrm{~B}$ \\
\hline WTIF- $22-297-14$ & W-9714 & 3769 & 273.8 & 0.28 & 8.645B & 1132 & v & u & 174.7 & $17.2 \mathrm{~J}$ & $\mathrm{u}$ & 42.09 & $41.66 \mathrm{~B}$ \\
\hline WTFF-92-297-71 & W-9771 & 39.36 & 292,1 & 0 & 10.11B & 1203 & $\mathrm{u}$ & $<0.5760$ & 228.9 & 15.7 & $<12.19$ & 42.12 & $40.66 \mathrm{~B}$ \\
\hline WTIT-92-297-74 & W-9774 & \begin{tabular}{|r|}
4042 \\
\end{tabular} & 301.1 & u & $\begin{array}{r}10.76 \\
\end{array}$ & \begin{tabular}{|r|}
1073 \\
\end{tabular} & $\mathrm{u}$ & $<0,5760$ & 222.4 & 17 & \begin{tabular}{|c|c|}
$<12.19$ \\
\end{tabular} & 44.50 & $43.03 \mathrm{~B}$ \\
\hline Detection Lifn' & $\mathrm{NM}$ & 3,947 TO 4.592 & $0.351 \mathrm{~T} 00,408$ & 0.15 & $1.228 \mathrm{~T} 01.429$ & 9123TO 106.1 & 2.5 & $0.326 \mathrm{T0} 0.612$ & $2.632 \mathrm{TO} 3.061$ & 0.05 & 11.1 T0 12.96 & 1225 TO 1,429 & 0.351 TO 0.409 \\
\hline
\end{tabular}


HINF-SD-WM-TD-018

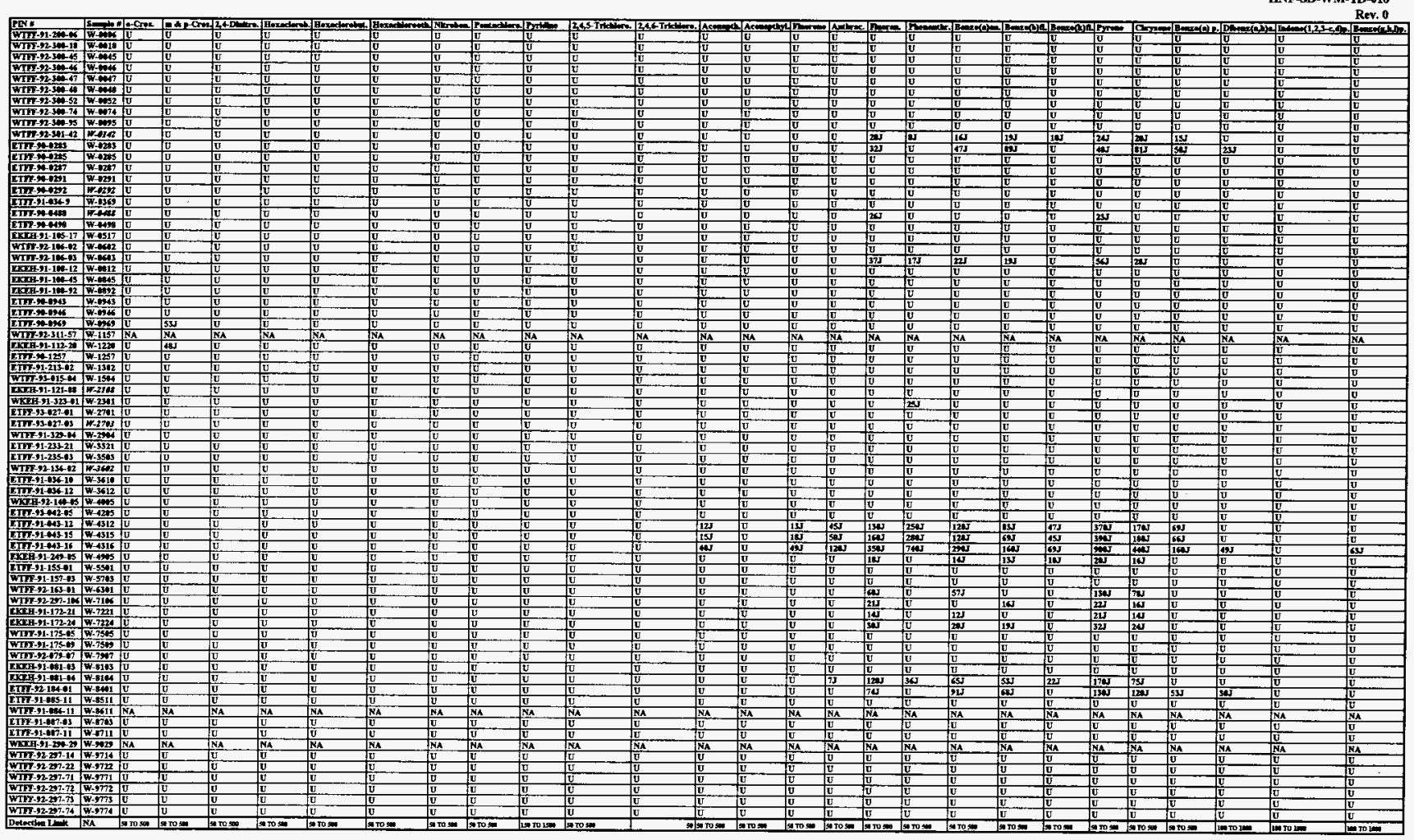

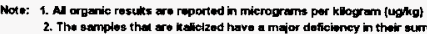




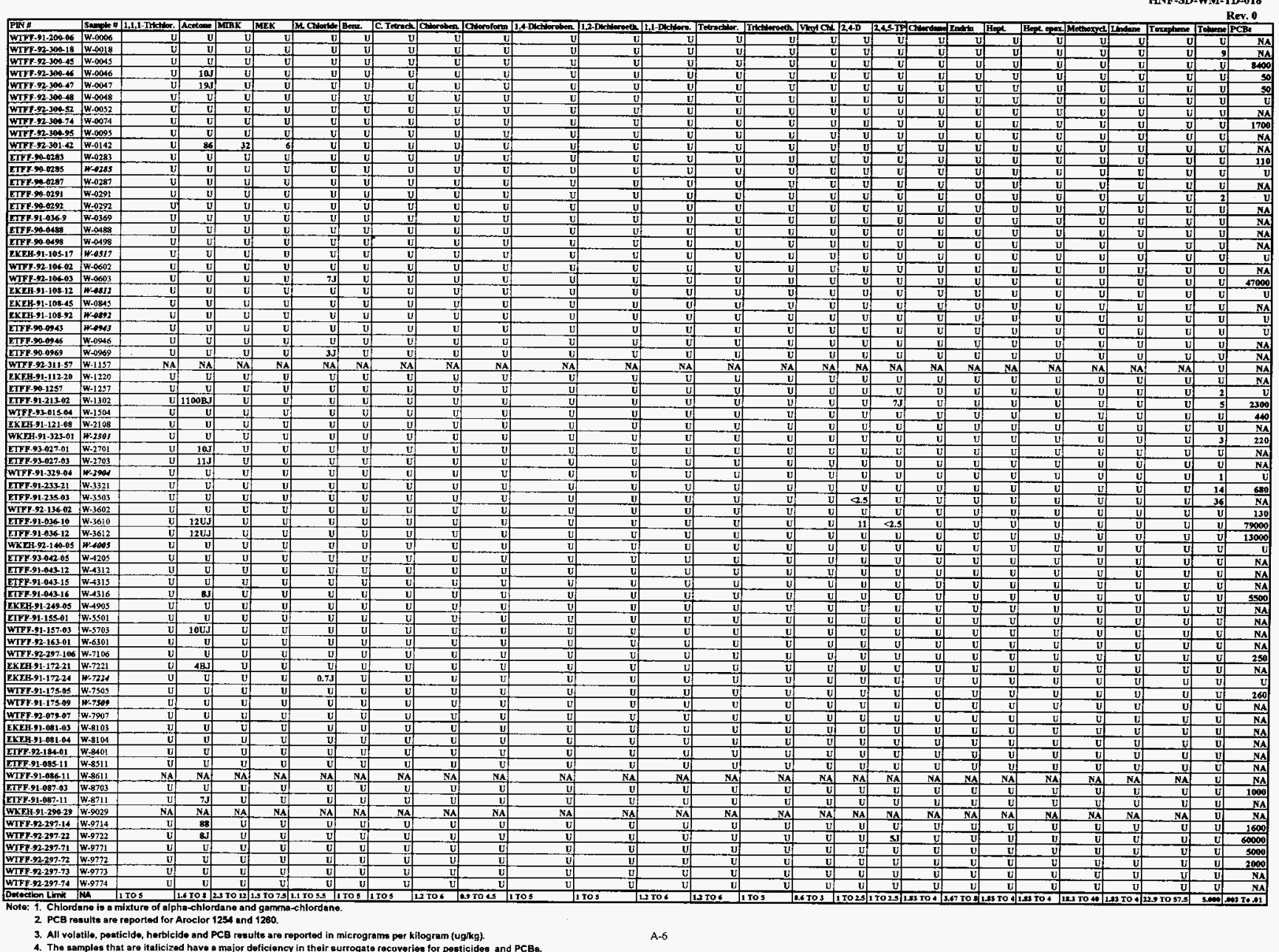




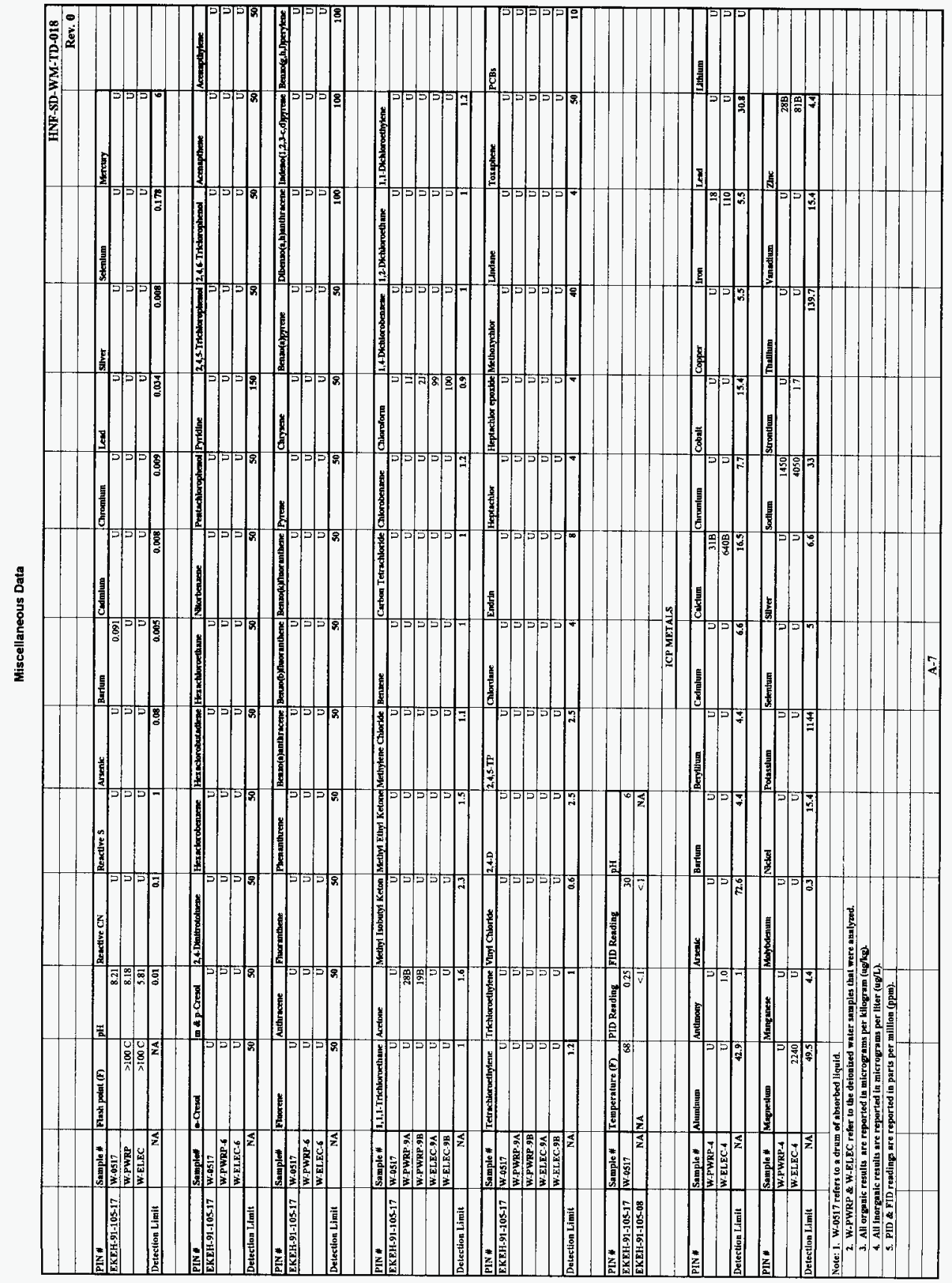


Rev. 0

\section{APPENDLX B}

\section{Field Data}

Comprised of 2 pages including the cover page 


\begin{tabular}{|c|c|c|c|c|c|c|}
\hline PIN \# & Sample \# & Temperature (F) & PID Reading (ppm) & FID Reading (ppm) & $\mathrm{pH}$ & Paint Filter \\
\hline WTFF-91-200-06 & W-00136 & $\begin{array}{r}76 \\
\end{array}$ & $<1$ & $<1$ & 6 & Neg \\
\hline WTFF-92-300-18 & W-0018 & 68 & 0.1 & $<0$ & 7 & Neg \\
\hline WTFF-92-300-45 & W-0045 & 76 & 0.15 & 0.3 & 7 & Neg \\
\hline WTFF-92-300-46 & W-0046 & 76 & 0.05 & 0.22 & 7 & Neg \\
\hline WTFF-92-300-47 & W.0047 & 76 & $<1$ & $<1$ & 7 & Neg \\
\hline WTFF-92-300-48 & W-0,048 & 70 & 0.19 & $<.01$ & 5 & Neg \\
\hline WTFF-92-300-52 & W-0052 & 76 & $\mathbf{0 . 2}$ & 0.5 & 6 & Neg \\
\hline WTFF-92-300-74 & W.0074 & 70 & 0.1 & $<1$ & 5 & Neg \\
\hline WTFF-92-300-95 & W-0095 & 76 & 0.35 & 0.32 & 7 & $\mathrm{Neg}$ \\
\hline WTFF-92-301-42 & W-0142 & 70 & 14 & 12 & st & $\mathrm{Neg}$ \\
\hline ETFF-90-10283 & W-13283 & 70 & 1.25 & 0.5 & 5 & Neg \\
\hline ETFF-90-0285 & W-0285 & 70 & 2.5 & 0.17 & 7 & Neg \\
\hline ETFF-90-0287 & W-0287 & 64 & $<1$ & $<.1$ & 4 & Neg \\
\hline ETFF-90-0291 & W-0291 & 70 & 0.1 & 0.1 & 4 & Neg \\
\hline ETFF-90-0292 & W-0292 & 64 & 0.5 & 2.2 & 5 & Neg \\
\hline ETFF-91-036-9 & W-0369 & 76 & 2 & 0.7 & 6 & Neg \\
\hline ETFF-90-0488 & W-0488 & 70 & 0.2 & 0.4 & 6 & Neg \\
\hline ETFF-90-0498 & W-0498 & 70 & 0.5 & 0.5 & 4 & Neg \\
\hline WTFF-92-106-02 & W-0602 & 70 & 0.46 & 0.1 & 5 & Neg \\
\hline WTFF-92-106-03 & W-0603 & 76 & $<1$ & $<1$ & 6 & Neg \\
\hline EKEH-91-108-12 & W-0812 & 70 & 0.15 & 0.33 & 5 & Neg \\
\hline EKEH-91-108-45 & W-0845 & 70 & $<.01$ & 0.1 & 4 & Neg \\
\hline EKEH-91-108-92 & W-0892 & 68 & 0.13 & $<0$ & 6 & Neg \\
\hline ETFF-90-0943 & W-0943 & 70 & $<1.0$ & 250 & 5 & Neg \\
\hline ETFF-90-0946 & W-0946 & 70 & 0.1 & 2,500 & 5 & Neg \\
\hline \begin{tabular}{|l|l|} 
ETFF-90-0969 \\
\end{tabular} & W-0969 & 76 & $<1$ & $<1$ & 6 & Neg \\
\hline WTFF-92-311-57 & W-1157 & 68 & 0.02 & 40 & 7 & Neg \\
\hline EKEH-91-112-20 & W-1220 & 68 & 0.1 & $>5,000$ & 6 & Neg \\
\hline ETFF-90-1257 & W-1257 & 70 & 0.08 & 0.16 & 6 & Neg \\
\hline ETFF-91-213-02 & W-1302 & 88 & 16 & 18 & 10 & Neg \\
\hline WTFF-93-015-04 & W-1504 & 64 & 0.25 & 0.25 & 4 & $\mathrm{Neg}$ \\
\hline EKEH-91-121-08 & W-2108 & 70 & 0.3 & 0.18 & 4 & $\mathrm{Neg}$ \\
\hline WKEH-91-323-01 & W-2301 & 70 & 0.5 & 0.2 & 4 & Neg \\
\hline ETFF-93-027-01 & W-2701 & 88 & 0.22 & 0.48 & 5 & $\mathrm{Neg}$ \\
\hline ETFF-93-027-03 & W-2703 & 69 & 26.8 & 0.1 & 5 & Neg \\
\hline WTFF-91-329-04 & $W-2904$ & 70 & 0.3 & 0.14 & 4 & Neg \\
\hline ETFF-91-233-21 & W-3321 & 70 & 0.5 & 0.23 & 6 & Neg \\
\hline ETFF-91-235-03 & W-3503 & 64 & 2 & 1.5 & 6 & Neg \\
\hline WTFF-92-136-02 & W-3602 & 70 & 0.3 & $<.1$ & 5 & Neg \\
\hline ETFF-91-036-10 & W-3610 & 68 & 0.11 & $<0$ & 6 & Neg \\
\hline ETFF-91-036-12 & W-3612 & 64 & 3 & 2 & 4 & Neg \\
\hline WKEH-92-140-105 & W-4005 & 68 & 0.12 & 3.5 & 7 & Neg \\
\hline ETFF-93-042-05 & W-4205 & 70 & 0.09 & $<.1$ & 6 & Neg \\
\hline ETFF-91-043-12 & W-4312 & 76 & 0.09 & 0.28 & 7 & Neg \\
\hline ETFF-91-043-15 & W-4315 & 76 & 0.14 & 0.25 & 6 & $\mathrm{Neg}$ \\
\hline ETFF-91-043-16 & W-4316 & 76 & $<1$ & $<1$ & 6 & Neg \\
\hline EKEH-91-249-05 & W-4905 & 70 & 0.2 & 0.24 & 5 & Neg \\
\hline ETFF-91-155-01 & W-5501 & 76 & 2 & $>350$ & 6 & $\mathrm{Neg}$ \\
\hline WTFF-91-157-03 & W-5703 & 64 & 1.2 & 5 & 4 & Neg \\
\hline WTFF-92-163-01 & W-6301 & 76 & 0.2 & 1.2 & 7 & $\mathrm{Neg}$ \\
\hline WTFF-92-297-106 & W-7106 & 64 & 0.3 & $<1$ & 6 & $\mathrm{Neg}$ \\
\hline EKEH-91-172-21 & W-7221 & 69 & 1 & 0.5 & 6 & $\mathrm{Neg}$ \\
\hline EKEH-91-172-24 & W-7224 & 68 & 0.03 & $<0$ & 6 & Neg \\
\hline WTFF-91-175-05 & W-7505 & 64 & 0.2 & $<1$ & 6 & Neg \\
\hline WTFF-91-175-09 & W-7509 & 64 & 0.5 & $<.2$ & 4 & Neg \\
\hline WTFF-92-079-07 & W-7907 & 70 & $<.1$ & $<1$ & 5 & Neg \\
\hline EKEH-91-081-03 & W-8103 & 70 & 0.1 & $<.01$ & 6 & Neg \\
\hline EKEH-91-081-04 & $\bar{W}-8104$ & 69 & 0.5 & 11 & 6 & Neg \\
\hline ETFF-92-184-01 & W-8401 & 64 & $<.1$ & 0.3 & 4 & Neg \\
\hline ETFF-91-085-11 & W-8511 & 76 & 5.24 & 0.5 & 7 & Neg \\
\hline WTFF-91-086-11 & W-8611 & 68 & 0.18 & $<0$ & 6 & Neg \\
\hline ETFF-91-087-03 & W-8703 & 64 & $<1$ & $<1$ & 4 & Neg \\
\hline ETFF-91-087-11 & W-8711 & 76 & $<1$ & $<1$ & 7 & Neg \\
\hline WKEH-91-290-29 & W-9029 & 68 & 2.4 & $<0$ & 6 & Neg \\
\hline WTFF-92-297-14. & W-9714 & 76 & $<1$ & $<1$ & 7 & Neg \\
\hline WTFF-92-297-22 & W.9722 & 68 & 0.04 & $<\theta$ & 7 & Neg \\
\hline WTFF-92-297-71 & W-9771 & 68 & 0.04 & 0.15 & 7 & $\mathrm{Neg}$ \\
\hline WTFF-92-297-72 & W-9772 & 76 & $<1$ & $<1$ & 6 & Neg \\
\hline WTFE-92-297-73 & W-9773 & 70 & 0.01 & 0.2 & (4) & Neg \\
\hline WTFF-92-297-74 & W-9774 & 76 & 0.15 & 0.2 & 6 & Neg \\
\hline
\end{tabular}

Notes: 1. The paint filter result "Neg" means that no liquid was observed. 
HNF-SD-WM-TD-018

Rev. 0

\section{APPENDIX C}

1996 Quality Assurance Data

Comprised of 5 pages including the cover page 


\section{Glossary of Organic Data Reporting Qualifiers}

B- Indicates the constituent was analyzed for and detected in the associated laboratory blank. This qualifier is applied by the laboratory. During the process of data validation this qualifier may be replaced by other appropriate qualifiers as defined by the validation procedures. The associated data should be considered usable for decision making purposes.

U- Indicates the constituent was analyzed for and not detected. The concentration reported is the sample quantitation limit corrected for aliquot size, dilution and percent solids (in the case of solid matrices) by the laboratory. The associated data should be considered usable for decision making purposes.

UJ- Indicates the constituent was analyzed for and not detected. Due to a minor quality control deficiency identified during data validation the concentration reported may not accurately reflect the sample quantitation limit. The associated data should be considered usable for decision making purposes.

J- Indicates the constituent was analyzed for and detected. This qualifier may be applied by the laboratory to indicate a concentration which is less than the contract required quantitation limit (CRQL) but greater than the instrument detection limit (IDL). During data validation this qualifier may be applied to indicate a minor quality control deficiency. However, in either case, the associated data should be considered usable for decision making purposes.

NJ- Indicates presumptive evidence of a constituent at an estimated value. This qualifier is normally applied to GC analysis data (such as organochlorine pesticide and PCB data). The associated data should be considered usable for decision making purposes.

N- Indicates presumptive evidence of a constituent. This qualifier is normally applied to GC analysis data (such as organochlorine pesticide and PCB data). The associated data should be considered usable for decision making purposes.

JN- Indicates a tentatively identified compound (TIC) whose concentration and identification have been determined to be valid as a result of data validation. The associated data should be considered usable for decision making purposes.

UJN- Indicates a tentatively identified compound (TIC) that has been determined to be presumptive and valid $(\mathrm{N})$ in terms of identification and quantitation and has been qualified as undetected $(\mathrm{U})$ due to associated blank contamination.

UR- Indicates the constituent was analyzed for and not detected. The concentration reported has been qualified as unusable due to a major quality control deficiency identified during data validation. The associated data should be considered unusable for decision making purposes.

R- Indicates the constituent was analyzed for and detected. The concentration reported has been qualified as unusable due to a major quality control deficiency identified during data validation. The associated data should be considered unusable for decision making purposes. 
Rev. 0

Variations in Sample Analysis Results taken from WSCF and Quanterra

WSCF: Packet\#96001100-WSC-036

Quanterra Packet\#W1088-QES-543

WSCF

\begin{tabular}{|l|l|}
\hline Sample\# & TCLP $(\mathrm{ug} / \mathrm{ml})$ \\
\hline & \\
\hline $\mathrm{W}-0291-3$ & $\mathrm{Ba}=.425$ \\
\hline $\mathrm{W}-0048-3$ & $\mathrm{Ba}=.286$ \\
\hline $\mathrm{W}-0283-3$ & $\mathrm{Ba}=.338$ \\
\hline $\mathrm{W}-0943-3$ & $\mathrm{Ba}=.236$ \\
\hline
\end{tabular}

\begin{tabular}{|l|l|}
\hline Sample\# & Semi-Volatiles \\
\hline & \\
\hline W-0283-4 & Benzo(b)Fluor $=89 \mathrm{ug} / \mathrm{mg}$ \\
\hline & Chrysene $=81 \mathrm{ug} / \mathrm{mg}$ \\
\hline
\end{tabular}

Quanterra

\begin{tabular}{|l|l|}
\hline Sample\# & TCLP (ug/l) \\
\hline & \\
\hline $\mathrm{Q}-0291-3$ & $\mathrm{Ba}=677.0$ \\
\hline $\mathrm{Q}-0048-3$ & $\mathrm{Ba}=575.0$ \\
\hline $\mathrm{Q}-0283-3$ & $\mathrm{Ba}=661$ \\
\hline $\mathrm{Q}-0943-3$ & $\mathrm{Ba}=396.0$ \\
\hline
\end{tabular}

\begin{tabular}{|l|l|}
\hline Sample\# & Semi-Volatiles \\
\hline & \\
\hline Q-0283-4 & Benzo(b)Fluor. $=99 \mathrm{ug} / \mathrm{L}$ \\
\hline
\end{tabular}

Notes: 1. The chart is representative of analysis results reported by two laboratories. for the purpose of comparing results.

2. The Waste Sampling \& Characterization Facility (WSCF) results begin with "W", while Quanterra results begin with " $Q$ ". 


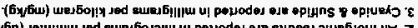

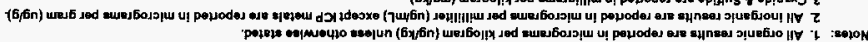

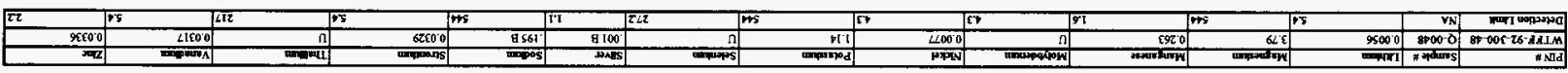

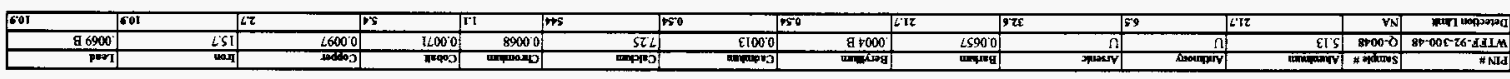

SIVIaW dOI
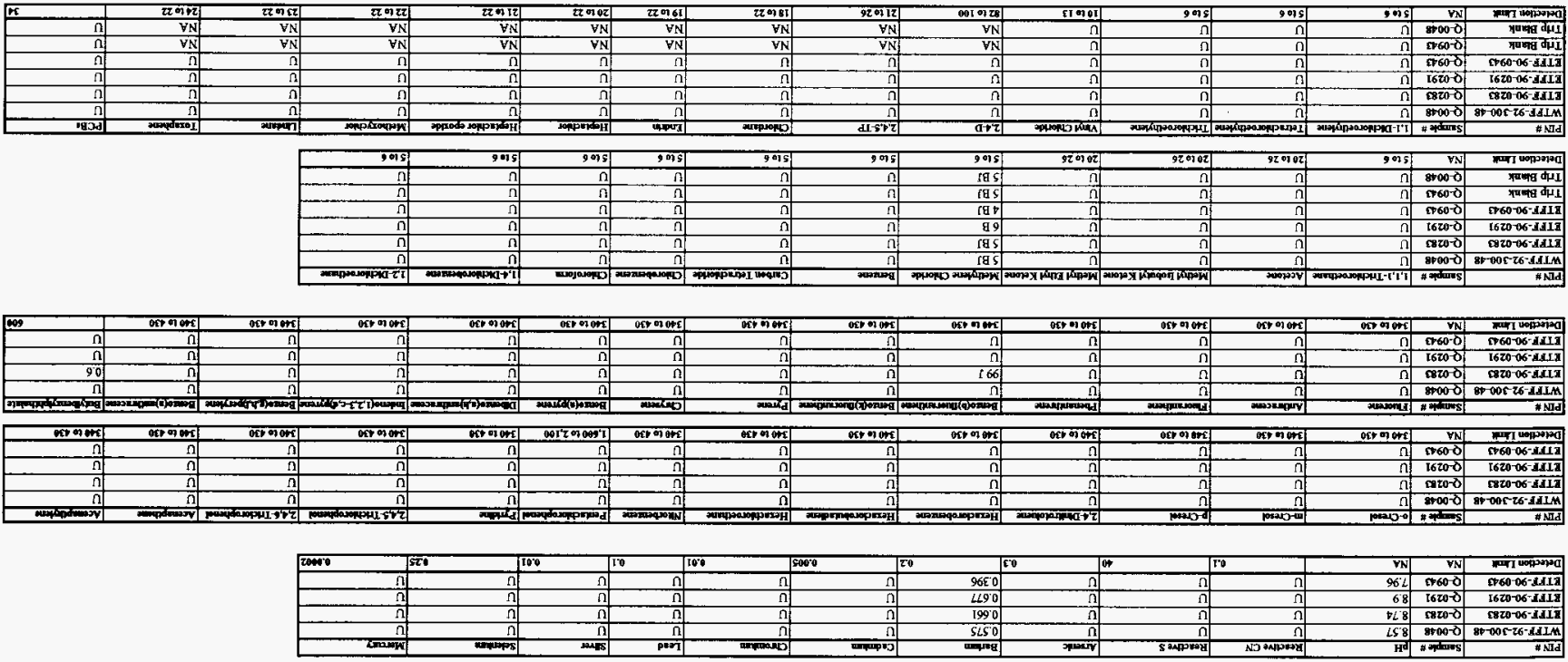

0 say

BLO-QI-WM-US-ANH

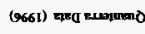

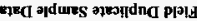



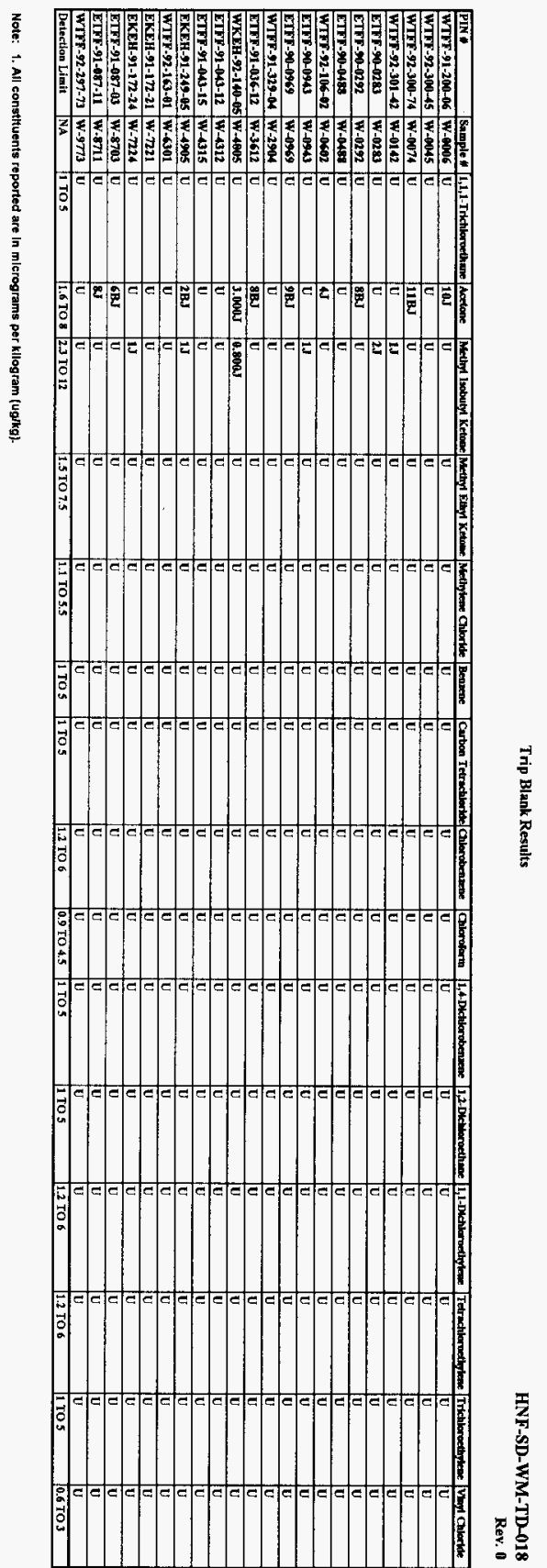
HNF-SD-WM-TD-018

Rev, 0

\section{APPENDIX D}

\section{Laboratory Results}

Comprised of 3 pages including the cover page

D-1 


\section{Glossary of Organic Data Reporting Qualifiers}

B- Indicates the constituent was analyzed for and detected in the associated laboratory blank. This qualifier is applied by the laboratory. During the process of data validation this qualifier may be replaced by other appropriate qualifiers as defined by the validation procedures. The associated data should be considered usable for decision making purposes.

U- Indicates the constituent was analyzed for and not detected. The concentration reported is the sample quantitation limit corrected for aliquot size, dilution and percent solids (in the case of solid matrices) by the laboratory. The associated data should be considered usable for decision making purposes.

UJ- Indicates the constituent was analyzed for and not detected. Due to a minor quality control deficiency identified during data validation the concentration reported may not accurately reflect the sample quantitation limit. The associated data should be considered usable for decision making purposes.

J- Indicates the constituent was analyzed for and detected. This qualifier may be applied by the laboratory to indicate a concentration which is less than the contract required quantitation limit (CRQL) but greater than the instrument detection limit (IDL). During data validation this qualifier may be applied to indicate a minor quality control deficiency. However, in either case, the associated data should be considered usable for decision making purposes.

NJ- Indicates presumptive evidence of a constituent at an estimated value. This qualifier is normally applied to $\mathrm{GC}$ analysis data (such as organochlorine pesticide and PCB data). The associated data should be considered usable for decision making purposes.

N- Indicates presumptive evidence of a constituent. This qualifier is normally applied to GC analysis data (such as organochlorine pesticide and PCB data). The associated data should be considered usable for decision making purposes.

JN- Indicates a tentatively identified compound (TIC) whose concentration and identification bave been determined to be valid as a result of data validation. The associated data should be considered usable for decision making purposes.

UJN- Indicates a tentatively identified compound (TIC) that has been determined to be presumptive and valid $(J N)$ in terms of identification and quartitation and has been qualified as undetected (U) due to associated blank contamination.

UR- Indicates the constituent was analyzed for and not detected. The concentration reported has been qualified as unusable due to a major quality control deficiency identified during data validation. The associated data should be considered unusable for decision making purposes.

R- Indicates the constituent was analyzed for and detected. The concentration reported has been qualified as unusable due to a major quality control deficiency identified during data validation. The associated data should be considered unusable for decision making purposes.

\section{D-2}




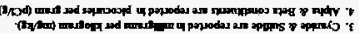

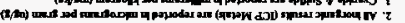

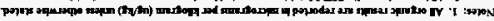
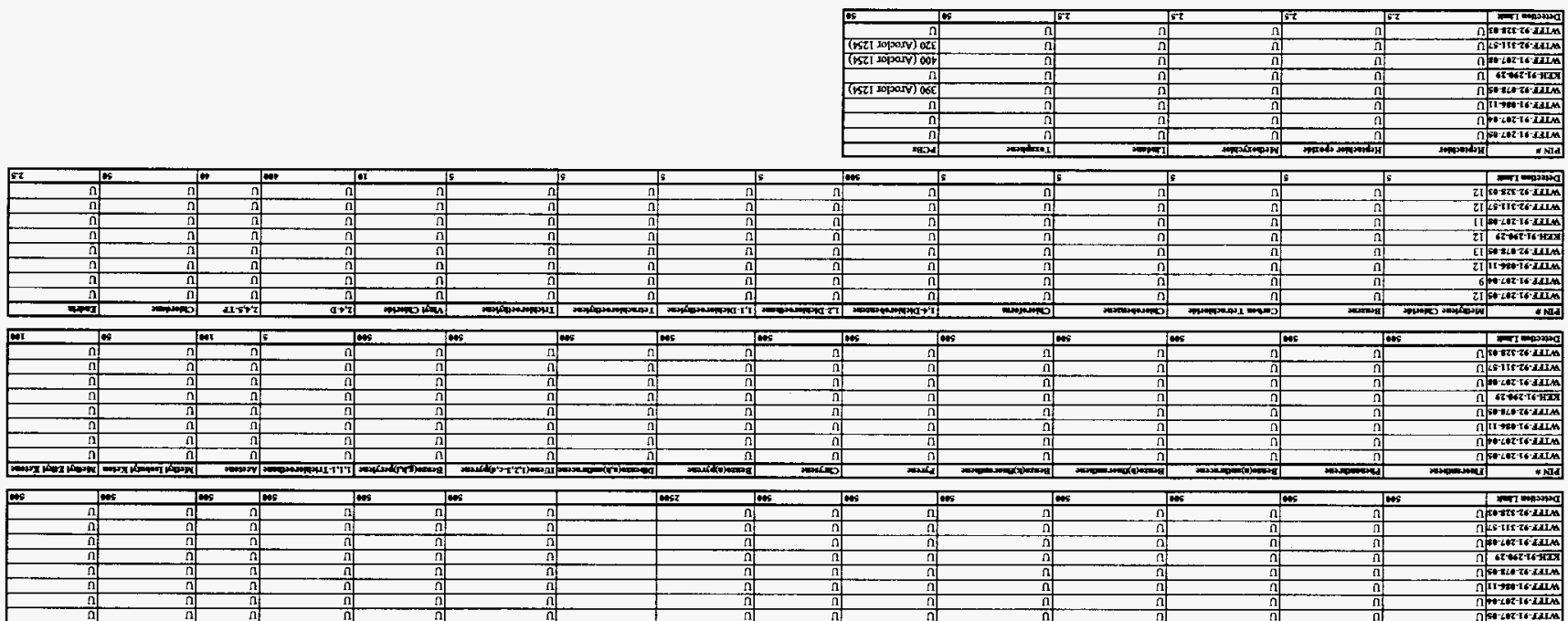

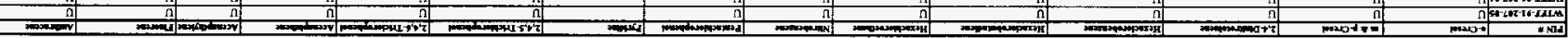
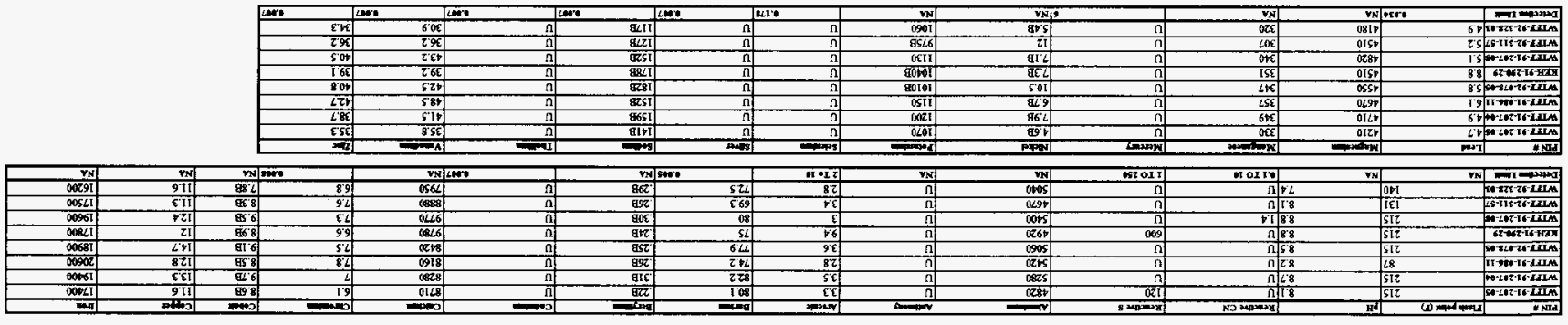
HNF-SD-WM-TD-018

Rev. 0

\section{APPENDIX E}

1996 Calculations

Comprised of 6 pages including the cover page 


\begin{tabular}{|c|c|c|}
\hline Chemical Name & Calculation of Weight $\%$ & Weight $\%$ \\
\hline Acenathene & $.040 \mathrm{mg} / \mathrm{kg} / 10,000=.000004 \%$ & $0.000004 \%$ \\
\hline Anthracene & $.12 \mathrm{mg} / \mathrm{kg} / 10,000=.000012 \%$ & $0.000012 \%$ \\
\hline Benzo(a)anthracene & $.29 \mathrm{mg} / \mathrm{kg} / 10,000=.000029 \%$ & $0.000029 \%$ \\
\hline Benzo(a)pyrene & $.16 \mathrm{mg} / \mathrm{kg} / 10,000=.000016 \%$ & $0.000016 \%$ \\
\hline Benzo(b)fluoranthene & $.16 \mathrm{mg} / \mathrm{kg} / 10,000=.000016 \%$ & $0.000016 \%$ \\
\hline Benzo(g,h,i)perylene & $.063 \mathrm{mg} / \mathrm{kg} / 10,000=.0000063 \%$ & $0.0000063 \%$ \\
\hline Benzo(k) fluoranthene & $.069 \mathrm{mg} / \mathrm{kg} / 10,000=.0000069 \%$ & $0.0000069 \%$ \\
\hline Chrysene & $.440 \mathrm{mg} / \mathrm{kg} / 10,000=.000044 \%$ & $0.000044 \%$ \\
\hline Dibenz $(\mathrm{a}, \mathrm{h})$ anthracene & $.049 \mathrm{mg} / \mathrm{kg} / 10,000=.0000049 \%$ & $0.0000049 \%$ \\
\hline Fluoranthene & $.35 \mathrm{mg} / \mathrm{kg} / 10,000=.000035 \%$ & $0.000035 \%$ \\
\hline Fluorene & $.049 \mathrm{mg} / \mathrm{kg} / 10,000=.0000049 \%$ & $0.0000049 \%$ \\
\hline Indeno(1,2,3-c,d) pyren & $.049 \mathrm{mg} / \mathrm{kg} / 10,000=.0000049 \%$ & $0.0000049 \%$ \\
\hline Phenanthrene & $.740 \mathrm{mg} / \mathrm{kg} / 10,000=.000074 \%$ & $0.000074 \%$ \\
\hline Pyrene & $.9 \mathrm{mg} / \mathrm{kg} / 10,000=.00009 \%$ & $0.00009 \%$ \\
\hline Total PAH\% & & $0.0003479 \%$ \\
\hline
\end{tabular}

Note: Total PAH\% is the sum of the weight percent of the constituents.

\begin{tabular}{|l|l|r|}
\hline Chemical Name & Calculation of Weight\% & Weight $\%$ \\
\hline 2,4-D & $.011 \mathrm{mg} / \mathrm{kg} / 10,000=.0000011 \%$ & $0.0000011 \%$ \\
\hline Methyl Ethyl Ketone & $.006 \mathrm{mg} / \mathrm{kg} / 10,000=.000000 \%$ & $0.0000006 \%$ \\
\hline Methyl Isobutyl Ketone & $.032 \mathrm{mg} / \mathrm{kg} / 10,000=.0000032 \%$ & $0.0000032 \%$ \\
\hline PCBs & $79 \mathrm{mg} / \mathrm{kg} / 10,000=.0079 \%$ & $0.0079 \%$ \\
\hline $2,4,5-T P($ Silvex) & $.007 \mathrm{mg} / \mathrm{kg} / 10,000=.0000007 \%$ & $0.0000007 \%$ \\
\hline Total HH\% & & $0.0079056 \%$ \\
\hline
\end{tabular}

\section{Metals \& Organics}

\begin{tabular}{|l|l|}
\hline Chemical Name & \multicolumn{1}{|c|}{ Maximum Result } \\
\hline Acetone & $88 \mathrm{ug} / \mathrm{kg} \times \mathrm{mg} / 1000 \mathrm{ug}=.088 \mathrm{mg} / \mathrm{kg}$ \\
\hline Barium & $.677 \mathrm{ug} / \mathrm{ml} \times \mathrm{mg} / 1000 \mathrm{ug} \times 1000 \mathrm{ml} / \mathrm{L}=.677 \mathrm{mg} / \mathrm{L}$ \\
\hline Chromium & $.166 \mathrm{ug} / \mathrm{ml} \times \mathrm{mg} / 1000 \mathrm{ug} \times 1000 \mathrm{ml} / \mathrm{L}=.166 \mathrm{mg} / \mathrm{L}$ \\
\hline o-Cresol \& m-Cresol & $53 \mathrm{ug} / \mathrm{mg} \times \mathrm{mg} / 1000 \mathrm{ug}=.053 \mathrm{mg} / \mathrm{kg}$ \\
\hline Lead & $2.99 \mathrm{ug} / \mathrm{ml} \times \mathrm{mg} / 1000 \mathrm{ug} \times 1000 \mathrm{~m} / \mathrm{L}=2.99 \mathrm{mg} / \mathrm{L}$ \\
\hline Mercury & $11 \mathrm{ug} / \mathrm{ml} \times \mathrm{mg} / 1000 \mathrm{ug} \times 1000 \mathrm{ml} / \mathrm{L}=11 \mathrm{mg} / \mathrm{L}$ \\
\hline Methylene Chloride & $3 \mathrm{ug} / \mathrm{kg} \times \mathrm{mg} / 1000 \mathrm{ug}=.003 \mathrm{mg} / \mathrm{kg}$ \\
\hline Silver & $.086 \mathrm{ug} / \mathrm{ml} \times \mathrm{mg} / 1000 \mathrm{ug} \times 1000 \mathrm{ml} / \mathrm{L}=.086 \mathrm{mg} / \mathrm{L}$ \\
\hline
\end{tabular}


CURRENT DATE -- 2/18/97

HAZARDOUS ANALYSIS SMART (HAS) SYSTEM

HAS SYSTEM REPORT FOR REOUEST * BACKLOO

PAGE - 1

MATERIAL -- EQUIVALENT CONCENTRATIONS FOR HALOGENATED HYDROCARBONS, FOLYAROMATIC HYDROCARBONS AND ORGANICS

ANALYSIS DATE - 12/20/96 CONTAINER -

WASTE PEYSICAL STATE - L TC PHYSICAL STATE - L

PH -

DENSITY -
DESIGNATOR - CLJ

WASTE WEIGHT -

/CC WASTE STATUS -

CONSTITUENT LIST FOR ITEM \#2-EC\&HHPERCENT

\begin{tabular}{|c|c|c|c|c|c|c|c|c|c|c|c|c|c|}
\hline $\begin{array}{l}\text { CAS\# } \\
\text { MSDS\#/RGN }\end{array}$ & $\begin{array}{l}\text { CHEMICAL } \\
\text { NAME }\end{array}$ & $\begin{array}{l}\text { WE IGHT } \\
\text { PERCENT }\end{array}$ & Tox & EC $x$ & $\begin{array}{l}\text { PERS/ } \\
\text { LDR }\end{array}$ & $\begin{array}{r}\text { SOUR } \\
\text { Use-Code-cls }\end{array}$ & $\begin{array}{l}\text { CES } \\
\text { LDR (WW/OT) }\end{array}$ & PRODUCT & D1 & $\begin{array}{l}40 \mathrm{CFR} \\
\mathrm{D} 2 \mid \mathrm{D} 3\end{array}$ & $\begin{array}{l}\text { TOXICITY CHARACTERIS } \\
\text { Code-DW conc.- }\end{array}$ & $\begin{array}{l}\text { STIC } \\
\text {-LDR conc. }\end{array}$ & $\begin{array}{l}\text { GENERAL } \\
\text { INFORMATION }\end{array}$ \\
\hline $\begin{array}{l}108-10-1 \\
\text { FORM- } \\
\text { TOT z OF CHE }\end{array}$ & $\begin{array}{l}\text { 4-METHYL-2- } \\
\text { PENTANONE } \\
\text { EM_ IN WASTE MATRIX }\end{array}$ & $\begin{array}{c}.0000 \\
.0000\end{array}$ & D & .0000 & & $\begin{array}{l}\mathrm{S}-\mathrm{F} 003-\mathrm{DW} \\
-\quad-\mathrm{DW}\end{array}$ & $\begin{array}{l}0.05 \text { ppm } \\
0.33 \text { ppon }\end{array}$ & $\begin{array}{l}\text { CODE - U161 } \\
\text { CLASS - DW } \\
\text { LDR-LDR- } \\
\text { POISON - }\end{array}$ & I & & $\begin{array}{cl}- & - \\
- & - \\
\text { NOTES : } 0.8 \text { G/ML DOT NAME: } \\
\text { ISOBUTYL KETONE }\end{array}$ & $\begin{array}{c}- \\
- \\
\text { METHYL. }\end{array}$ & $\begin{array}{l}\mathrm{RQ}-2270 \\
\mathrm{FP}-73{ }^{\circ} \mathrm{F} \\
\mathrm{RD}-5 / 17 / 95\end{array}$ \\
\hline $\begin{array}{l}120-12-7 \\
\text { FORM- } \\
16 \\
\text { TOT. \% OF CHE }\end{array}$ & EM. IN WASTE MATRIX & $\begin{array}{l}.0000 \\
.0000\end{array}$ & $\mathrm{~N}$ & 0.0000 & PAH & $\begin{array}{ll}- & - \\
- & -\end{array}$ & & $\begin{array}{l}\text { CODE - } \\
\text { CLASS - } \\
\text { LDR- - } \\
\text { POISON - }\end{array}$ & & & $\begin{array}{c}- \\
- \\
\text { NOTES: }\end{array}$ & - & $\begin{array}{l}R Q-2270 \text { o K } \\
F P- \\
R D-1 / 26 / 95\end{array}$ \\
\hline $\begin{array}{l}129-00-0 \\
\text { FORM- } \\
\text { TOT. } \% \text { OF CHE }\end{array}$ & $\begin{array}{l}\text { PYRENE } \\
\text { M. IN WASTE MATRIX }\end{array}$ & $\begin{array}{l}.0001 \\
.0001\end{array}$ & D & .0000 & PAH & $\begin{array}{ll}- & - \\
- & -\end{array}$ & & $\begin{array}{l}\text { CODE - } \\
\text { CLASS - } \\
\text { LDR- - } \\
\text { POISON - }\end{array}$ & & & $\begin{array}{c}- \\
- \\
\text { NOTES : }\end{array}$ & - & 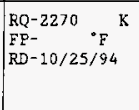 \\
\hline $\begin{array}{l}1319-77-3 \\
\text { FORM- } \\
31 \\
\text { TOT. \% OF CHE }\end{array}$ & ERESOL & $\begin{array}{l}.0000 \\
.0000\end{array}$ & D & .0000 & & $\begin{array}{l}\text { S-F004-DW } \\
-\quad-D W\end{array}$ & $\begin{array}{l}2.82 \mathrm{ppm} \\
0.75 \mathrm{ppm}\end{array}$ & $\begin{array}{l}\text { CODE - U052 } \\
\text { CLASS - DW } \\
\text { LDR-LDR- } \\
\text { POISON - }\end{array}$ & & $x$ & $\begin{array}{l}\text { D026-200 ppm - } \\
\text { NOTES: } 1.04 \mathrm{G} / \mathrm{ML}\end{array}$ & $\begin{array}{l}-200 \text { ppn } \\
-\end{array}$ & $\begin{array}{l}R Q-454 \text { of } \mathrm{K} \\
\mathrm{FP}-{ }^{\circ} \mathrm{F} \\
\mathrm{RD}-1 / 09 / 95\end{array}$ \\
\hline $\begin{array}{l}1336-36-3 \\
\text { FORM- } \\
\text { TOT. \% OF CHE }\end{array}$ & $\begin{array}{l}\text { POLYCELORINATED } \\
\text { BIPEENYLS } \\
\text { EM. IN WASTE MATRIX }\end{array}$ & $\begin{array}{l}.0079 \\
.0079\end{array}$ & D & .0000 & $\begin{array}{l}\mathrm{HH} \\
\mathrm{LDR}\end{array}$ & $\begin{array}{ll}- & - \\
- & -\end{array}$ & & $\begin{array}{l}\text { CODE - } \\
\text { CLASS - } \\
\text { LDR- - } \\
\text { POISON - }\end{array}$ & & & $\begin{array}{c}- \\
\text { NOTES: }\end{array}$ & - & 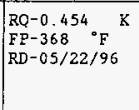 \\
\hline $\begin{array}{l}\text { 191-24-2 } \\
\text { FORM- } \\
\text { TOT. } 2 \text { OF CHE }\end{array}$ & $\begin{array}{l}\text { BENZO (GHI) } \\
\text { PERYLENE } \\
\text { EM. IN WASTE MATRIX }\end{array}$ & $\begin{array}{l}.0000 \\
.0000\end{array}$ & $\mathrm{~N}$ & 0.0000 & PAH & $=\quad-$ & & $\begin{array}{l}\text { CODE - } \\
\text { CLASS - } \\
\text { LDR- - } \\
\text { POISON - }\end{array}$ & & & - & - & $\begin{array}{l}\mathrm{RQ}-2270{ }^{\circ} \mathrm{K} \\
\mathrm{FP}- \\
\mathrm{RD}-12 / 30 / 94\end{array}$ \\
\hline $\begin{array}{l}193-39-5 \\
\text { FORM- } \\
\text { TOT. ₹ OF CHE }\end{array}$ & $\begin{array}{l}\text { INDENO(1,2,3- } \\
\text { Cd)PYRENE } \\
\text { EM. IN WASTE MAIRIX }\end{array}$ & .0000 & $\mathrm{~N}$ & 0.0000 & $\mathrm{PAH}$ & $\begin{array}{ll}- & - \\
- & -\end{array}$ & & $\begin{array}{l}\text { CODE - U137 } \\
\text { CLASS - DW } \\
\text { LDR-LDR- } \\
\text { POISON - }\end{array}$ & & & NOTES: & - & $\begin{array}{l}\mathrm{RQ}-45.4 \\
\mathrm{FP}-{ }^{\circ} \mathrm{K} \\
\mathrm{RD}-9 / 26 / 94\end{array}$ \\
\hline $\begin{array}{l}\text { 205-99-2 } \\
\text { FORM- } \\
\text { TOT. } \approx \text { OF CHE }\end{array}$ & $\mid \begin{array}{l}\text { BENZ }(\theta) \text { ACEFHENANTHR } \\
\text { YLENE } \\
\text { EM. IN WASTE MATRIX }\end{array}$ & .0000 & $\mathrm{~N}$ & 0.0000 & PAH & $\begin{array}{ll}- & - \\
- & -\end{array}$ & & $\begin{array}{l}\text { CODE - } \\
\text { CLASS - } \\
\text { LDR- - } \\
\text { POISON - }\end{array}$ & & & NOTES : & - & $\begin{array}{l}\mathrm{RQ}-.454 \text { 的 } \\
\mathrm{FP}-\mathrm{F}^{\circ} \\
\mathrm{RD}-9 / 26 / 94\end{array}$ \\
\hline
\end{tabular}


CURRENT DATE -- $2 / 18 / 97$

MATERIAL -- EQUIVALENT CONCENTRATIONS FOR HALOGENATED HYDROCARBONS, POLYAROMATIC HYDROCARBONS AND ORGANICS

ANALYSIS DATE - 12/20/96 CONTAINER -

WASTE PHYSICAL STATE - L TC PHYSICAL STATE - L

$\mathrm{pH}-$
FLASHPOINT -

DENSITY

PAGE - 2

CONSTITUENT LIST FOR ITEM \#2-EC\&HHPERCENT

\begin{tabular}{|c|c|c|c|c|c|c|c|c|c|c|c|c|c|c|}
\hline $\begin{array}{l}\text { CAS\# } \\
\text { MSDS } \# / R G N\end{array}$ & $\begin{array}{l}\text { CHEMICAL } \\
\text { NAME }\end{array}$ & $\begin{array}{r}\text { WEIGHT } \\
\text { PERCENT }\end{array}$ & Tox & EC $\pi$ & $\begin{array}{l}\text { PERS/ } \\
\text { LDR }\end{array}$ & $\begin{array}{r}\text { SoIJ } \\
\text { Use-Code-cls }\end{array}$ & $\begin{array}{l}\text { CES } \\
\text { LDR (WW/OT) }\end{array}$ & PRODUCT & D1 & $40 \mathrm{CF}$ & $\begin{array}{l}\mathrm{FR} \\
\mathrm{D} 3\end{array}$ & $\begin{array}{l}\text { TOXICITY C } \\
\text { Code-DW conc - }\end{array}$ & $\begin{array}{l}\text { CHARACTERISTIC } \\
\text {-LDR conc. }\end{array}$ & $\begin{array}{l}\text { GENERAL } \\
\text { INEORMAT ION }\end{array}$ \\
\hline $\begin{array}{l}206-44-0 \\
\text { FORM- } \\
\text { TOT. } \% \text { OF }\end{array}$ & $\begin{array}{l}\text { FLUORANTHENE } \\
\text { HEM, IN WASTE MATRIX }\end{array}$ & $\begin{array}{l}.0000 \\
.0000\end{array}$ & D & .0000 & PAH & $\begin{array}{ll}- & - \\
- & -\end{array}$ & & $\begin{array}{l}\text { CODE - U } 120 \\
\text { CLASS - DW } \\
\text { LDR-LDR- } \\
\text { POISON - }\end{array}$ & & & & NoTES: & - & $\begin{array}{l}R Q-45.4 \quad \mathrm{~K} \\
F P={ }^{\circ} \mathrm{F} \\
\mathrm{RD}-1 / 26 / 95\end{array}$ \\
\hline $\begin{array}{l}207-08-9 \\
\text { FORM- } \\
\text { TOT. } ₹ \text { OF }\end{array}$ & $\begin{array}{l}\text { BENZO (K) } \\
\text { FLUORANTHENE } \\
\text { HEM. IN WASTE MATRIX }\end{array}$ & $\begin{array}{l}.0000 \\
.0000\end{array}$ & $\mathrm{~N}$ & 0.0000 & PAH & $\begin{array}{ll}- & - \\
- & -\end{array}$ & & $\begin{array}{l}\text { CODE - } \\
\text { CLASS - } \\
\text { LDR- - } \\
\text { POISON - }\end{array}$ & & & & NOTES: & $\overline{-}$ & $\begin{array}{l}\mathrm{RQ}-2270 \text {. } \mathrm{K} \\
\mathrm{FP}-{ }^{\circ} \mathrm{F} \\
\mathrm{RD}-1 / 26 / 95\end{array}$ \\
\hline $\begin{array}{l}\text { 218-01-9 } \\
\text { FORM- } \\
16 \\
\text { TOT. } \approx \text { OF O }\end{array}$ & $\left.\right|_{\text {IEM. IN WASTE MATRIX }} ^{\text {CHRYSENE }}$ & .0000 & N & 0.0000 & PAH & $\begin{array}{l}- \\
-\end{array}$ & & $\begin{array}{l}\text { CODE - U050 } \\
\text { CLASS - DW } \\
\text { LDR-LDR-1 } \\
\text { POISON - }\end{array}$ & & & & - & $\overline{-}$ & $\begin{array}{l}R Q-45.4 \text { of } \mathrm{R} \\
\mathrm{FP}-\text { of }^{2} \\
\mathrm{RD}-1 / 26 / 95\end{array}$ \\
\hline $\begin{array}{l}50-32-8 \\
\text { FORM- } \\
\text { I6 } \\
\text { TOT. \& OF }\end{array}$ & $\begin{array}{l}\text { BENZO (A) PYRENE } \\
\text { IEM. IN WASTE MATRIX }\end{array}$ & $\begin{array}{l}.0000 \\
.0000\end{array}$ & $\mathrm{~N}$ & 0.0000 & PAH & $=\quad-$ & & $\begin{array}{l}\text { CODE - U022 } \\
\text { CLASS - DW } \\
\text { LDR-LDR-1 } \\
\text { POISON - }\end{array}$ & & & & $\begin{array}{c}- \\
- \\
\text { NOTES : }\end{array}$ & - & 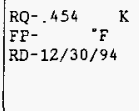 \\
\hline $\begin{array}{l}53-70-3 \\
\text { FORM- } \\
\text { TOT. } \& \text { OF C }\end{array}$ & $\begin{array}{l}\text { DIBENZANTHRACENE, } \\
1,2,5,6^{-} \\
\text {HEM. IN WASTE MATRIX }\end{array}$ & $\begin{array}{l}.0000 \\
.0000\end{array}$ & $\mathrm{~N}$ & 0.0000 & PAH & 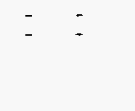 & & $\begin{array}{l}\text { CODE - U063 } \\
\text { CLASS - AHW } \\
\text { LDR-LDR-1 } \\
\text { POISON - }\end{array}$ & & & & $\begin{array}{r}- \\
\text { NOTES: }\end{array}$ & - & $\begin{array}{l}\mathrm{RQ}-.454 \quad \mathrm{~K} \\
\mathrm{FP}-{ }^{\circ} \mathrm{F} \\
\mathrm{RD}-12 / 30 / 94\end{array}$ \\
\hline $\begin{array}{l}56-55-3 \\
\text { FORM- } \\
\text { TOT. \& OF C }\end{array}$ & BEN2(a) ANTHRACENE & $\begin{array}{l}.0000 \\
.0000\end{array}$ & $\mathrm{~N}$ & 0.0000 & PAH & $\begin{array}{ll}- & - \\
- & -\end{array}$ & & $\begin{array}{l}\text { CODE - J018 } \\
\text { CLASS - DW } \\
\text { LDR-LDR- } \\
\text { POISON - }\end{array}$ & & & & $\begin{array}{c}- \\
- \\
\text { NOTES: }\end{array}$ & - & $\begin{array}{l}\mathrm{RQ}-4,54 \quad \mathrm{~K} \\
\mathrm{FP}-{ }^{\circ} \mathrm{F} \\
\mathrm{RD}-1 / 26 / 95\end{array}$ \\
\hline $\begin{array}{l}67-64-1 \\
\text { FORM-L } \\
19 \\
\text { TOT. \& OF C }\end{array}$ & $\begin{array}{l}\text { ACETONE } \\
\text { M. IN WASTE MATRIX }\end{array}$ & .0000 & N & 0.0000 & & $\begin{array}{c}S-F 003-D W \\
-\quad-D W\end{array}$ & $\begin{array}{l}0.05 \mathrm{ppm} \\
0.59 \mathrm{ppm}\end{array}$ & $\begin{array}{l}\text { CODE - UOO2 } \\
\text { CLASS - DW } \\
\text { LDR-LDR - } 1 \\
\text { POISON - }\end{array}$ & I & & & $\begin{array}{cr}- & - \\
- & - \\
\text { NOTES }: 0.79 \mathrm{G} / \mathrm{ML}\end{array}$ & $\overline{-}$ & $\begin{array}{l}\mathrm{RQ}-2270 \text { K } \\
\mathrm{FP}-0 \\
\mathrm{RD}-11 / 2 / 95\end{array}$ \\
\hline $\begin{array}{l}75-09-2 \\
\text { FORM-2 } \\
\text { TOT. } X \text { OF C }\end{array}$ & IEM. IN WASTE MATRIX & .0000 & D & .0000 & $\mathrm{HH}$ & $\begin{array}{l}D-F 001-D W \\
S-F 002-D W\end{array}$ & $\begin{array}{l}0.20 \mathrm{ppm} \\
0.96 \mathrm{ppm}\end{array}$ & $\begin{array}{l}\text { CODE - UO80 } \\
\text { CLASS - DW } \\
\text { LDR-LDR- } \\
\text { POISON - }\end{array}$ & & & & $\begin{array}{c}- \\
- \\
\text { NOTES : } 1.33 \text { G/ML } \\
\text { CHLORIDE }\end{array}$ & $\begin{array}{ll}- & - \\
- & - \\
\text { L DOT NAME: METHYLENE }\end{array}$ & $\left\{\begin{array}{l}\mathrm{RQ}-454 \quad \mathrm{~K} \\
\mathrm{EP}-\mathrm{O}^{\circ} \mathrm{F} \\
\mathrm{RD}-11 / 1 / 95\end{array}\right.$ \\
\hline
\end{tabular}


HNF-SD-WM-TD-018

Rev. 0

CURRENT DATE -- 2/18/97

HAS SYSTEM REPORT FOR REQUEST \# BACKLOG PAGE - 3 MATERIAL -- EQUTVALENT CONCENTRATIONS FOR HALOGENATED HYDROCARBONS, POLYAROMATIC HYDROCARBONS AND ORGANICS ANALYSIS DATE - $12 / 20 / 96$ CONTAINER WASTE PHYSICAL, STATE - L TC PHYSICAL STATE - L

pHe DENSITY

CONSTITUENT LIST FOR ITEM \#2-EC\&HAPERCENT

\begin{tabular}{|c|c|c|c|c|c|c|c|c|c|c|c|c|c|}
\hline $\begin{array}{l}\text { CAS\# } \\
\text { MSDS\#/RGN }\end{array}$ & $\begin{array}{l}\text { CHEMICAL } \\
\text { NAME }\end{array}$ & $\begin{array}{r}\text { WEIGHT } \\
\text { PERCENT }\end{array}$ & Tox & EC $x$ & $\begin{array}{l}\text { PERS/ } \\
\text { LDR }\end{array}$ & $\begin{array}{r}\text { SOUR } \\
\text { Use-Code-cls }\end{array}$ & $\begin{array}{l}\text { RCES } \\
\text { LDR (WW/OT) }\end{array}$ & FRODUCT & D1 & $\begin{array}{l}40 \mathrm{CFR} \\
\mathrm{D} 2 \mid \mathrm{D} 3\end{array}$ & $\begin{array}{l}\text { TOXICITY C } \\
\text { Code-DW conc.- }\end{array}$ & $\begin{array}{l}\text { STIC } \\
-I D R \operatorname{con} c .\end{array}$ & $\begin{array}{l}\text { GENERAI } \\
\text { INFORMATION }\end{array}$ \\
\hline $\begin{array}{l}78-93-3 \\
\text { FORM-L } \\
19 \\
\text { TOT. 2 OF CHE }\end{array}$ & NETHYL ETHYL KETONE & $\begin{array}{l}.0000 \\
.0000\end{array}$ & D & .0000 & & $\begin{array}{r}5-F 005-D W \\
-\quad-D W\end{array}$ & $\begin{array}{l}12.7 \mathrm{ppm} \\
0.96 \mathrm{ppm}\end{array}$ & $\begin{array}{l}\text { CODE - U1S9 } \\
\text { CLASS - DW } \\
\text { LDR-LDR-1 } \\
\text { POISON - }\end{array}$ & I & & $\begin{array}{c}\text { D035-200 ppm } \\
- \\
\text { NOTES: } 0.81 \mathrm{G} / \mathrm{ML}\end{array}$ & $\begin{array}{l}-200 \mathrm{ppm} \\
-\end{array}$ & $\begin{array}{l}R Q-2270 \\
F P-26 \\
R D-9 / 20 / 94\end{array}$ \\
\hline $\begin{array}{l}83-32-9 \\
\text { FORM- } \\
16 \\
\text { TOT. X OF CHE }\end{array}$ & ACENAPHTHENE & $\begin{array}{l}.0000 \\
.0000\end{array}$ & N & 0.0000 & $\mathrm{PAH}$ & $\begin{array}{ll}- & - \\
- & -\end{array}$ & & $\begin{array}{l}\text { CODE - } \\
\text { CLASS - } \\
\text { LDR- - } \\
\text { POISON - }\end{array}$ & & & - & - & $\begin{array}{l}\mathrm{RQ}-45.4 \text { o } \mathrm{X} \\
\mathrm{FP}-\text { of }^{\circ} \\
\mathrm{RD}-3 / 28 / 95\end{array}$ \\
\hline $\begin{array}{l}85-01-8 \\
\text { FORM- } \\
\text { TOT. }\{\text { OF CHE }\end{array}$ & EMENANTHRENE & $\begin{array}{l}.0001 \\
.0001\end{array}$ & N & 0.0000 & PAE & $\begin{array}{ll}- & - \\
- & -\end{array}$ & & $\begin{array}{l}\text { CODE - } \\
\text { CLASS - } \\
\text { LDR- - } \\
\text { POISON - }\end{array}$ & & & $\begin{array}{r}- \\
- \\
\text { NOTES: }\end{array}$ & - & $\begin{array}{l}\text { RQ-2270 \& } \mathrm{K} \\
\mathrm{FP}-\text { of }^{2} \\
\mathrm{RD}-1 / 26 / 95\end{array}$ \\
\hline $\begin{array}{l}86-73-7 \\
\text { FORM- } \\
\text { TOT. } ₹ \text { OF CHE }\end{array}$ & FLUUORENE & $\begin{array}{l}.0000 \\
.0000\end{array}$ & N & 0.0000 & PAH & $\begin{array}{ll}- & - \\
- & -\end{array}$ & & $\begin{array}{l}\text { CODE - } \\
\text { CLASS - } \\
\text { LDR- - } \\
\text { POISON - }\end{array}$ & & & $\begin{array}{c}- \\
- \\
\text { NOTES: }\end{array}$ & - & $\begin{array}{l}\mathrm{RQ}-2270 \\
\mathrm{EP}-{ }^{\circ} \mathrm{K} \\
\mathrm{RD}-1 / 10 / 95\end{array}$ \\
\hline $\begin{array}{l}93-72-1 \\
\text { FORM-S } \\
\text { TOT. I OF CBF }\end{array}$ & $\begin{array}{l}2,4,5-T P \text { SILVEX } \\
\text { EM. IN WASTE MATRIX }\end{array}$ & $\begin{array}{l}.0000 \\
.0000\end{array}$ & D & .0000 & $\begin{array}{l}\text { HH } \\
\text { LDR }\end{array}$ & $\begin{array}{r}0-F 027-D W \\
-\quad-D W\end{array}$ & $\begin{array}{l}\text { N/A } \\
\text { NONE }\end{array}$ & $\begin{array}{l}\text { CODE - } \\
\text { CLASS - } \\
\text { LDR- - } \\
\text { POISON - }\end{array}$ & & & $\begin{array}{l}\text { D017-I ppm } \\
- \\
\text { NOTES: }\end{array}$ & $\begin{array}{l}-1 \text { ррm } \\
-\end{array}$ & $\begin{array}{l}\text { RQ-45.4 K K } K \\
F P-N O N E{ }^{\circ} F \\
R D-11 / 13 / 95\end{array}$ \\
\hline $\begin{array}{l}\text { GCNOO1 } \\
\text { FORM- } \\
\text { TOT. } \angle \text { OF CRE }\end{array}$ & $\begin{array}{l}\text { REMAINDER NON- } \\
\text { HAZARDOUS PER THE } \\
\text { MANUFACTURER } \\
\text { EM. IN WASTE MATRIX }\end{array}$ & $\mid \begin{array}{l}100.0000 \\
100.0000\end{array}$ & $\mathrm{~N}$ & 0.0000 & & $\begin{array}{l}- \\
-\end{array}$ & & $\begin{array}{l}\text { CODE - } \\
\text { CLASS - } \\
\text { LDR- - } \\
\text { POISON - }\end{array}$ & & & $\begin{array}{c}- \\
\text { NOTES: }\end{array}$ & - & $\begin{array}{l}\text { RQ-NONE K } \mathrm{K} \\
\text { FP- } \\
\text { RD-10/24/91 }\end{array}$ \\
\hline
\end{tabular}


HNF-SD-WM-TD-018

Rev. 0

CURRENT DATE - 2/18/97 PACE - 4 MATERIAL -- EQUIVALENT CONCENTRATIONS FOR HALOGENATED HYDROCARBONS, POLYAROMATIC HYDROCAREONS AND ORGANICS ANALYSIS DATE 12/20/96 CONTAINER WASTE PHYSICAL STATE - $i$ TC PHYSICAL STATE - L

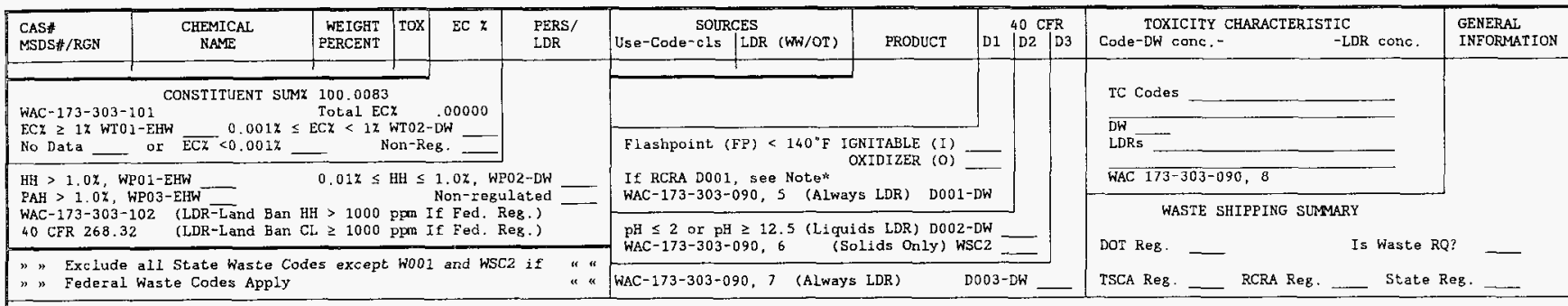

DESIGNATION INFORMATION FOR ITEM \# 2-EC\&HHPERCENT OF REQUEST \#BACKLOC

APPLICABLE WASTE CODES WASTE CLASS IDR CODES PROPER SHIPEING NAME HAZARD CLASS DOT ID NO LABELS PACKAGING REQUIREMENTS SHIP TO CELL (IF APPLICABLE)

* Reference $49 \mathrm{CFR}$ 173.120, and 173,121 for DOT Proper Shipping Name and Packing Group

z Halogenated Hydrocarbons (HH) not applicable per the testing method described in WAC 173-303-110
PH DENSITY -
DESIGNATOR - CLJ WASTE WEIGHT WASTE STATUS - 